\title{
Lustration (administrative justice) and closure in post-communist East Central Europe
}

\author{
Liviu Damsa \\ University of Warwick School of Law, \\ Coventry CV4 7AL, UK \\ E-mail: L.T.Damsa@warwick.ac.uk
}

\begin{abstract}
This article discusses the various dimensions of East Central Europe's closure with the communist past, and then assesses the impact of transitional justice measures in the closure with communism. Special attention is paid to the so called 'lustration', which in the view of the author performs important functions in transitions to democratic regimes, related to the reconstruction of a moral and rational community, and to the closure with the communist past. The article shows that the failures and controversies surrounding 'lustration' were due to its radical potential of reconstruction of a moral-rational democratic community, and also to specific socio-political factors of the post-communist ECE. What specific features of ECE post-communist transitions and of lustration conducted to the recurrence of debates related to the communist past is a question that has not been addressed heretofore, despite a fairly well-developed literature on post-communist administrative justice.
\end{abstract}

Keywords: Central Eastern Europe; lustration; communist; administrative; closure; transitional justice.

Reference to this paper should be made as follows: Damsa, L. (2011) 'Lustration (administrative justice) and closure in post-communist East Central Europe', Int. J. Public Law and Policy, Vol. 1, No. 4, pp.335-375.

Biographical notes: Liviu Damsa is a $\mathrm{PhD}$ candidate at the Warwick Law School, The University of Warwick. He graduated summa cum laude from the University of Illinois College of Law LLM Program and obtained his LLB degree from the Alexandru Ioan Cuza University, Faculty of Law, Iasi, Romania.

\section{Introduction: The East-Central Europe's two decades of questioning the past}

Not late after the fall of the communist regimes in East-Central Europe (thereafter ECE) the transitional governments in the region found themselves busy with the dismantling of pre-existing structures of communist rule, and with the creation of new structures to take their place. For the purpose of the dismantling of old structures, a variety of transitional justice measures were deployed. Among such measures prominently figured the so called 'lustration,' consisting in the vetting or purges of former communist agents from positions of state authority. Albeit none could predict at the time how long or painful the 
transition to democratic regimes would be, a speedy closure of the communist past was arguably expected, at least as partial result of the lustration.

However, more than twenty years after the monumental changes of 1989, we can ascertain that one of the salient features of the post communist transition in East Central Europe has-been the almost never ending public debate regarding the communist past and its relationship with the present. ${ }^{1}$ The communist past, often prompted in the public debates by waves of cyclical, high profile, political scandals, has been used to question the directions of the post-communist transformations. ${ }^{2}$ The alleged links between a compromised past and the murky political present of the actors involved in such political scandals have been advanced in journalistic discourses or in the politicians' reciprocal accusations as 'proofs' of inefficacy of post-communist policies of rupture with the communist regime.

High on the list of topics related to this communist past stood the legacy of the communist secret police and the post-communist political trajectories or careers of its officers, agents and collaborators. ${ }^{3}$ Because in the political debates or journalistic discourses the lines between the past and the present were intertwined and blurred, a curious phenomenon happened. Thus, on one hand, the public opinion of Eastern and Central Europe countries has been suffering from an information overload, as it has been bombarded with various disclosures of public officials' communist past in all sort of post 1989 scandals in which such officials were involved. ${ }^{4}$ On the other hand, however, the public opinion still does not know much in terms of what the secret communist police did, who were its victims, who were its agents, who collaborated and for what reasons, and what became of the former agents and the collaborators during the transitional period.

Nevertheless, more than two decades down the road of 'transition', and with all the former East Central European communist countries now in the European Union after remarkable political and economic changes, this never ending debate generated by cyclical waves of political scandals could appear unexpected or paradoxical. ${ }^{5}$ Particularly unexpected if we think that at the onset of the post-communist ECE transitions, several countries from the region enacted administrative justice measures which had as main purpose the elimination of former communist secret services agents and collaborators from positions of public authority, and consequently to eliminate the possibility of such scandals. Paradoxical, if we think that in these countries such measures became permanent, despite their characterisation by legislators, courts, and scholars as temporary, and necessary only after the regime changes. ${ }^{6}$ The paradox become even clearer, if we think that in the ECE countries which did not enact such legislation at the onset of post-communist transitions, a reversal of an earlier trend of impunity from vetting and lustration could be detected. ${ }^{7}$ If legal measures supposed to close the past could not prevent scandals related to this past to occur with regularity, why such measures are adopted? Moreover, if such measures are not only inefficient, but also defined as temporary and justified only on a limited time span after a regime change, then why tend them to become permanent, or are enacted many years after the regime change?

Irrespective of such paradoxes, the continuous debates related to communist past and the trends related to administrative justice in the region, suggest, a still impossible closure, which warrants an investigation of causes which rendered the closure impossible until now. ${ }^{8}$

However, such an investigation is generally missing in the literature on the subject, which earlier during the post-communist transition focused more on the perceived 
incompatibility between lustration and the rule of law. More recently, however, Monica Nalepa provided a game theoretic explanation to the recurrence of lustration enactments in Eastern Central Europe. ${ }^{9}$ She also provided an answer to the question why governments dominated by former communists, opposing in principle to lustration measures, which have the potential to affect their political careers, enact such legislation many years after the fall of communism. ${ }^{10}$

We chose however to follow an alternative investigation to that of Nalepa, and to provide an explanation of such enactments based on ethics and political philosophy. Although Nalepa offers in our judgment a good model of explanation for politicians' behaviour, she arguably left outside her interpretation other possible factors that could explain the longevity and salience of lustration. After all, the politicians enact laws not only because such laws further their (political) interests, but arguably also because such laws correspond to a more ideal, normative vision $\mathrm{s}$ of societies, shared by their constituencies. Such an explanation is complementary to that offered by Nalepa. Nevertheless, given the limitations of space, we do not attempt to provide in this essay a fully developed theoretical argument, based on rigorous and extended empirical material. As the lustration policies followed in the post-communist ECE space varied enormously, the presentation of such an argument would need an extended space, which we do not have. Therefore, we only provide here a rough argument, and a starting point for further investigations related to the remarkable longevity of lustration in the former communist ECE space. Thus, we chose not to treat in extension the various lustration measures enacted at different moments of transition in different ECE countries, but only refer to cases, which in our view exemplify our theoretical position, or support our argument. For similar reasons of space, we could not treat other cases when imperfect transitional justice measures led to an increased demand for 'justice', in particular in the Latin American context. ${ }^{11}$ While the problems we tackle in this essay are specific to the postcommunist ECE space, it is clear that they are not unique to the post-communist settings, and have a broader application in transitional justice contexts. ${ }^{12}$ Nevertheless, we have to limit our investigation to the post-communist context. We try however to compensate in part for such limitations, by linking more explicitly closure with lustration. Although 'closure' is arguably an important goal of transitional justice, ${ }^{13}$ since in its absence the transitional societies could not move toward democratic consolidation it was not linked systematically to post-communist transitional measures, in post-communist studies. More recently, though, 'closure' was discussed in rapport to transitional justice mechanisms, such as truth commissions, ${ }^{14}$ albeit the discussion was not extended to the postcommunist settings. We hope thus to fill this gap of the post-communist transitional justice literature with respect to 'closure' and to the methods employed for closing. Similarly, 'lustration' seems to be a transitional justice mechanism poorly theorised in the early post-communist studies, since its longevity in post-communist societies cannot be explained by such theorisation. By offering an alternative conceptualisation to 'lustration', partially based on the concept of 'closure', we also hope to offer new directions for conceptualising this transitional justice mechanism, important in the post-communist settings. We also hope to offer a better explanation to the question why lustration, which was seen as temporary transitional measure, proved itself so salient and long lasting in post-communist societies.

The argument we wish to advance is the following. 'Closure' is arguably an important goal in the transitions from authoritarian or totalitarian rule to a democratic polity. Its attainment allows the victims and agents of the former autocratic state the possibility to 
put their terrible past behind them, and to join efforts in the construction of a new, democratic polity. It also allows the institutions of the democratic state to consolidate, and offers legitimacy and authority to such institutions. Nevertheless, 'closure' is an elusive goal. As a concept, 'closure' receives more than one definition, and it is susceptible of conceptualisation in several distinct directions, not necessarily related.

Because the closure with the communist past seemed to be affected by ways in which we conceive closure, and by the means deployed for closing, our thesis is that the still impossible closure with this past has to do with the characteristics and purposes of one of the main legal devices employed for closure, that of lustration. ${ }^{15}$

More specifically, we will argue that for particular reasons, among the various legal devices which can be used for closure, 'lustration' became the main legal device used for post communist closure. Further, we will argue that 'lustration' is more than a simple legal device, as it is seen sometimes in the literature. It is a radical measure, which in post-communist transformation was used in order to (re)establish by a single legal act not only a democratic polity, but also a moral one. ${ }^{16}$

As a radical measure deployed to (re) establish a 'moral community', lustration was plagued by all the dilemmas and problems which in the moral debates affect the delimitation of the moral actors from the immoral ones. In addition, the opponents of lustration were able to use a particular strong meaning of 'rule of law' and other concepts found in the democratic discourse to focus the debate on the shortcomings of the legislation, and to divert the attention from the (re)distributive justice aspects of lustration. ${ }^{17}$ Nevertheless the normative appeal of lustration was there to stay and probably shared by majorities in the ECE space. ${ }^{18}$ And this appeal explains, in addition to politicians self interests, the initiation of cyclical discussion and adoption of lustration measures in some countries of the ECE space. ${ }^{19}$

In order to defend this thesis, we will start with an analysis of several meanings of 'closure'. Then we will advance an explanation why a particular meaning of closure, related to the reconstruction of a democratic polity based on rational-moral agents, became so important in post-communism, and in general to transitions to democratic rule. We will further attempt to provide a link between this meaning of closure as reconstruction of a rational-moral democratic community and lustration, the post-communist transitional measure which, by force of the circumstances, became the exclusive legal instrument of dealing with the past. Additionally, we will briefly analyse how other different meanings of closure are related to transitional justice measures. We will also provide a tentative scorecard of the impact of other post-communist transitional measures on closure with communism. By doing this, we are hopeful to show that in the post-communist settings, the inconsistent and imperfect use of transitional justice measures, combined with particular evolutions of the state and society, led to an increased abstract demand for justice. Because after a decade of post-communist 'transition' the other transitional justice measures (criminal retribution and redress for victims) started to vanish from public agendas, the only transitional justice measure of salience left in the ECE space, by force of the circumstances, was lustration. ${ }^{20}$ Nevertheless, the increased abstract demand for justice put a pressure on the politicians to enact some transitional justice measures. This pressure explains in part, the longevity of lustration. However, lustration itself is a complex device, which in order to be efficient relies on the availability of the communist secret services archives, and on the smooth functioning of the legal system of the country applying it. As none of these important conditions was met in the ECE space, with the exception of the former GDR, lustration 
was plagued by a myriad of problems which impeded on its efficacy. To exemplify some of these problems, we will finally provide a simple model of establishing reports with former regime actors and apply this model to the post-communist context.

We will conclude with a summary and with some predictions about the future of such legislation.

\section{The post-communist closure concept and its challenges}

Because the impossible closure we mentioned might have intuitively to do with our understanding of what is to close, why 'that' particular object should be closed, and the methods used to close, it makes sense to start the investigation of the causes which impede the closure from a definition of the object of closure.

On this purpose, we could assume first that 'communism', as a political and economic system was the object of closure. However, the problem of definition is complicated because no description of such an object can take place outside of a context. Communism, or rather the 'real existing socialism' which was implemented through the ECE space, meant more than one thing depending on the place and the time, and usually meant simultaneously several things. ${ }^{21}$

As a system total domination of society, imposed from outside in most of the region, it meant a brutal destruction of all the democratic institutions of society, and their replacement with institutions totally dominated by the communist parties in the late forties and early fifties. ${ }^{22}$ In various places and times, as for example in the GDR in ' 53 , Hungary in '56, Czechoslovakia in ' 68 , or Poland during most of the time, communism also meant waves of popular revolts, brutally repressed by internal or external forces led by the Soviets. In all the places after its consolidation, it meant at least in principle total control of the economy by the Party state, and an economy of perpetual shortages and deprivation, organised from the top down. ${ }^{23}$ In addition, it also meant a pervasive and constant surveillance, which applied not only to the common citizens but also to the surveyors themselves and to their bosses. And as a rule, it meant a rigid state and bureaucracy, organised top down and totally dominated by the party, in which the law was a mere instrument and pure formality, and the truth was aggressively mystified by an ideology of total domination of the society. ${ }^{24}$

On the other hand, from an economic or social standpoint, the 'real existing socialism' meant: "another tentative of the ECE self perceived periphery of Europe to modernise and catch with a perceived centre. ${ }^{, 25}$ In its most dramatic period, ${ }^{26}$ in parallel with the brutal destruction of the old cultural, economic, and political elites, socialism also meant at least for some, unparalleled social mobility in the modern history of these countries. ${ }^{27}$

During and after that period, besides the endemic penury and widespread surveillance, it also meant a paternalistic state, which redistributed in one way or another the surplus accumulated. So despite communism's bias towards industrialisation at the expense of anything else in society, it was this redistribution and the large system of welfare which it entailed, that made the system supportable for a majority of population. ${ }^{28}$

But if the communism meant so many things, and not all of them negative, which of them were to be closed in order to obtain the desired closure? 
An obvious response is that the negative ones have to be closed, In particular the total domination of society by the party state, with its accompanying long set of wrongs, as for example the brutal repression, truth manipulation, pervasive and constant surveillance, or the perpetual economic shortages and deprivation have to be 'closed' ${ }^{29}$ However, in the post communist context, such a choice of wrongs 'in need of closure' might not be a straightforward exercise, as the perceptions related to wrongs in the region were the product of a mixture of personal as well as ideological and cultural considerations. ${ }^{30}$ Nevertheless, as all the successor regimes declared that they wanted to close the most egregious manifestations of communism as a political and economic system, and in particular the total domination of the state and society by the communist party, we could assume for the purpose of the argument a kind of uniform perception related to the object of closure, even if such uniform perception was lacking in reality.

\subsection{Justifications and normative purpose of closure}

If the object of closure was defined to include the 'communism' as a system, and more specifically the most egregious wrongs of communism, a second set of intuitive question related to closure might appear. The first such intuitive question is why should be 'that' object closed? And consequently, what purpose serves or it should serve the closing? In other words, what are the justifications of closure, and what is its normative purpose?

If the object of closure is taken to be the 'communist system', then there is no obvious or straight answer 'why' should such an 'object' be 'closed'.

For example, if one takes the common meaning of closure, as representing a "cessation of operations, termination or conclusion", she might say that because 'communism' imploded in the ECE, it was 'closed' by the act of implosion. The 'why' in this context is not a justification for action, but just an acknowledgement of a result produced by force majeure, or by an impersonal process of the society.

However, such representation of closure is objectionable on several grounds. First, it is objectionable because it does not answer the question why should be 'closed' the 'communist system'. Second, it is objectionable on the following ground. When we speak about societies it is implausible to think that all the institutions, which are common to all societies, including the communist ones, cease to operate following the implosion of a political system. And it is more plausible to think that such institutions will continue their functioning. As they continue their functioning, it is also plausible to imagine that some of their unpleasant features which characterised their functioning in the past would be conserved by inertia, at least for a period. In such a context, closure would imply the termination of these unpleasant features, respectively the wrongs associated with communism in our case. However, as the communist institutions survived by inertia, some of the unpleasant characteristics of the real existing socialism survived in the functioning of the society and its institutions after the implosion of communism, so these characteristics needed closure. ${ }^{31}$ The imperfection of such closure explains why after the communism was declared deceased by implosion, a death certificate detailing the closure of its 'unpleasant' characteristics which had still to be produced was late in coming.

Third, the deterministic understanding of closure as an act of implosion of communism excludes the consideration of the role of people in the process of closing, which arguably counts for more. If communism imploded in the ECE, it did at least in part because of the people actions and beliefs. 
When people took the streets in huge demonstrations against the ECE communist regimes in 1989 in spite of risks related to their physical integrity or their life, they did it so at least in part because they believed that socialism had became unsupportable. And that the daily moral and physical harm produced by communism was less bearable than the risk of getting arrested, tortured or shot by the communist regime's repression forces. $^{32}$ Therefore, it should be more in the 'closure' than just the bare acknowledgment of implosion of a political system, and it might have to do with the actions and beliefs of the people.

Nevertheless, in respect to people, closure has a meaning related to psychological trauma, and this psychological meaning becomes important in defining the parameters of closure. $^{33}$

More important, in polities such as those of the ECE under communism, where harm to others was state sponsored, most of the subjects were traumatised in one way or another. So closure means healing, large scale healing, and in this process "dealing with the reality and consequences" of past abuse is essential, at least for victims and perpetrators. ${ }^{34}$ Moreover, given its potential to eliminate the seeds of the future societal conflicts and to break an uninterrupted cycle of societal violence, the dealing with the past abuses became important for the society as a whole. ${ }^{35}$ However painful, delicate and long are the processes which contribute to healing, the society had therefore an interest in their initiation and development, interest dictated by self preservation. ${ }^{36}$ And it was this conceptualisation of closure as healing, which contributed in more recent transitions from authoritarian rule, such as those underwent in ECE, to a paradigmatic shift from impunity to accountability and confrontation with a nation's past. ${ }^{37}$ Memory, reparations and criminal punishment were institutionalised and used as main vehicles for healing.

Nonetheless, in regard to trauma, and in particular to the universal and severe harm that produced trauma in communism, there are also moral and political philosophy insights which offer to the concept of closure with communism not only an additional and deeper meaning, but also important justifications. Although an extensive examination of the philosophical debates generated by these insights are well beyond the purpose of the present analysis, we will attempt provide a brief overview of them. On this purpose we will contrast the assumptions about the individual and community made in the 'Leninist model', as described by Alain Besançon, to the assumptions made in democratic theory about the individual and community. Thus, as a system of power, communism was based on widespread violence, and on the constant breaking of the first universal requirement of the morals, 'do not harm' the others. ${ }^{38}$ These characteristics derived from the Leninist conception of inexistence of a common good as reason for which the political community exists, conception which was at odds with the Aristotelian and the classical conceptions on this matter. ${ }^{39}$

More completely, the communist project applied in the ECE derived from what Alain Besançon termed 'the three' levels of Leninist' Manichaeism, which could be described shortly as follows. ${ }^{40}$ As there is no common good, there is no political community, and the State, being in the service of a class, has as function not the arbitration but the domination. There is no solidarity between social groups, and the proletariat does not acknowledge any duty towards other social groups. However, the class which the party-state serves is not that of a proletariat in the physical sense, but the idea of proletariat, as provided by ideology. Hence, the party, using the violence of the State, should also model the physical proletariat to resemble the ideal. So, the party-state is actually not engaged, nor has it any obligation toward the proletariat in a physical sense. 
And this follows from the fact that the party does not represent the proletariat because of a democratic delegation, but on the virtue of a mystical one. Therefore, the party is only engaged for the superior interests of the socialism, as defined by the ideology. And from this follows that at the centre of the party is not the stable personnel composed by professional revolutionaries, as some believed, but an immaterial one: the ideological knowledge. With the constitution of the party, the cosmic fight between good and bad had found its centre. ${ }^{41}$ Nevertheless, this original Leninist political conception was not the only difference which made Lenin's political project so radically divergent from the classical democratic one. In addition to its political conception, as a totalising theory Leninism had also advanced an 'original' conception about the truth, and one in respect to ideology. With respect to 'truth', Leninism derived from its ontological dualism the dissolution of the truth, which it does not have any longer existence in itself, but is doubled. ${ }^{42}$ "Truth of whom? Liberty, for what? ...will respond immediately Lenin. There is no common reality...", in the words of Besançon. And it was precisely this introduction of a dualist way of thinking in a monist world, which was so at odds with the classical way of thinking, and it created so many intellectual problems for the 'bourgeois' political man who saw duplicity and (de) doubling of thinking where it was only a doubling of the reality for Lenin. Tactically brilliant as it was, this doubling of reality was not to solve the problem of the truth. The truth will return as a problem when the Bolshevik party took the power in Russia, and it was confronted with a social reality which did not quite match its expectations.

However, in case of conflict between the reality and what the party wanted, the ideology would be the ordering principle and ultimate arbiter of the conflict. Thus the contradiction between the social reality and that prescribed by the ideology was to be solved, as we known, in the favour of the ideology, by mystification of the truth to fit the ideological prescription. ${ }^{43}$ And also by physical and psychological violence on a scale rarely encountered in the human history. From this original Leninist vision related to the role of the ideology, the communist political project in ECE never truly liberated itself, despite its innumerable mutations during its 45 years of existence. ${ }^{44}$

To sum up, the communist political project in ECE inherited from the original Leninist conceptions a series of assumptions and judgments which in their core are as follows: there is no common good in the political community, but a cosmic war between opposite forces; the force of good, represented by the party, is endowed with ideological knowledge which sits at the centre; the party does not owe anything to any social group and does not represents any class, but an ideational proletariat, on the virtue of a mystical delegation; there is a double reality and therefore a double truth; there is no common rationality but infantilised social groups which should be led by force, if necessary, by the depositary of the total knowledge towards the shinning future; when the social reality diverges from that prescribed by ideology, it should be moulded by force to fit the ideological one.

In sharp contrast to the Leninist conception, in the classical view of democracy the people are organised in a political community, and ruled by themselves. Cooperation becomes the salient feature in democracy, and not the total domination of society for the purpose of transforming it to the prescription provided by ideology, as it was for Lenin.

Further, while it is presumptuous to speak of general unified conception of democracy given the tremendous diversity among the classical and modern thinkers on the subject, one common assumption among different thinkers is that the people in democracy are rational. ${ }^{45}$ This implies that persons endowed with rationality come in one 
way or another to make decisions which bind afterwards all, in the pursuit of a common good. Unlike the Leninist habitant of socialist polity who, if not in possession of the lights given by ideology was to be treated by the party-state as infantile and without rationality, the citizen of the democratic polity is assumed to be endowed with rationality and treated as such by his fellow habitants and the democratic state. Nevertheless, it is precisely this endowment with rationality, which makes possible to any person the understanding of the main moral requirement to not harm others, and in turn attach a new meaning to the closure with communism. To understand this meaning, imagine for example a communism agent who harmed others and now is supposed to become a member of a democratic polity that assumes its members to be endowed with (a basic moral) rationality. Practically, such a former communist agent who harmed others could only have two claims. First, she could claim that she is not endowed with the (minimum) universal rationality that enables her to distinguish the main requirement of the morals, and as a consequence excludes herself from the democratic political community. Or, she could claim her endowment with rationality, and become a habitant of the democratic space, In this case, however, she cannot discharge a priori the possible assignment of moral responsibility for her past acts, because the universal rationality and the morals it supports applies retroactively and take precedence over the 'communist' (i)rationality. ${ }^{46}$ In both situations a sort of exclusion operates as a result of democratic theory's conceptualisation of people as endowed with rationality. And a double constitution or reconstitution operates: one of a political community endowed with rational actors, and one of a moral community. This double reconstitution solves two of the most intractable problems inherited from the communism. First it solves the problem of the schisophrenic communist 'rationality', where rational actors had to justify the break of the main prescription of morals 'do not harm the others', on an unimaginable scale (as it was sponsored and sanctioned by the communist state). Second, it solves the problem of impossible societal cooperation under communism generated by the fear of the harm produced by others. When it rejects or sanctions the breakers of the moral imperatives, the double reconstitution of community operated by democratic theory's assumptions not only that it makes social cooperation possible again, but it returns to the fore the universal rationality, And it bases the functioning of the new polity on a radical different basis than that of the former polity under communism. In the end, by liberating the universal rationality from justifications and constrains imposed under communism, the reconstitution of community contributes to the healing of trauma produced by the communism's universal harm.

To conclude this discussion, we will say that closure with communism means from a democratic point of view a double (re)constitution, of a moral and rational political community. Having seen this, we should also note that this (re)constitution operates not only at a political level but also at a legal one, where criminal or administrative sanctions are imposed on the communist agents. ${ }^{47}$ In addition, we should note that in the post communist context, the most radical double (re)creation of a democratic community by legal means was attempted not at the level of criminal law, by definition restricted, but at the level of the administrative law, respectively at the level of the so called 'lustration'. ${ }^{48}$

Although the recreation of a moral and rational community was in general not posited expressly as a goal by the ECE legislators who introduced 'lustration' on the post communist agenda, a remarkable such manifesto is provided by the first ECE political program which projected the morality of public life as a major objective of post communist transformations. This is represented by the point 8 of the Declaration of 
Timisoara, Romania, of 11 March 1990. The declaration, largely ignored afterwards in media or scholarship, addressed the immediate post-communist context of Romania, where a former important communist, Ion Iliescu declared the intention of his quasipolitical organisation to transform itself in a party after it took over all the formidable machinery of the Romanian communist state, and to participate in the next round of elections, in spite of initial contrary declarations. ${ }^{49}$ Because Ion Iliescu and his followers were perceived as liars and manipulators who had as undeclared goal to preserve the power in communist hands, the declaration of Timisoara addressed a set of principles under which the political life in post-communism should be organised. Although the point 8 of the declaration was clearly written with

Iliescu's situation in mind, its language is more in the direction of a general political programme than it is toward a particular situation. As such, it is therefore applicable to all the countries breaking with communism. Moreover, it has the merit of defining, for the first time in ECE space, the moral responsibility of communist agents in the context of democratic transition, the sphere of those morally responsible, and also to project explicitly the re-constitution of a moral community as one of the major objectives of post communism.

Thus, accordingly to the point 8 :

\begin{abstract}
"The office of the President of Romania has to be one of our symbols of departure with communism. To be a member of the [communist] party is not a fault. We all know on what extent was conditioned the life of the individual under communism, from professional achievement to the receipt of a dwelling, by the red card, and what serious consequences could attract its surrender. Activists, however, were those people who have abandoned the profession to serve the Communist Party and to enjoy special privileges offered by it. A man who made such a choice presents no moral warranties which should be provided by a President." 50
\end{abstract}

Some authors did not escape to equal the legal manifestation of this reconstruction of a rational and moral space with a ritual cleansing. ${ }^{51}$ If we recall that Besançon described the magic role performed by communist ideological propaganda in annihilating the differences between the reality and the ideological prescriptions, the comparison of reconstruction with a ritual cleansing is probably not out of mark, as it makes sense to liberate from the communist ideological spell with the help of another magic move. ${ }^{52}$ Yet the legal device devised to reconstruct a rational and moral space by eliminating the communists from public life, that of lustration, not only that diverged sharply from the Roman lustrum that played such magical role and with which was compared, but had more mundane origins. ${ }^{53}$ So, if it was dictated by magic at all, it was perhaps more in the sense of a quasi-religious comportment emptied of any religious significance described by Mircea Eliade, in one of the classical books related to transmutations of religious comportments devoid of initial religious significance in modern life ${ }^{54}$, than in a sense of a veritable ritual cleansing. And in any case, its value was not a religious one, but a very practical one from the perspective of the passage to a democratic regime.

Finally, we should note that in addition to the meanings described until now, closure with communism has also a meaning related to an historical and long term perspective. In this regard closure would mean a long collective psycho-social and political process, in which a prominent role would be played by the understanding of the collective and personal responsibility for the communism wrongs, and the forging of a new, democratic identity. ${ }^{55}$ 
While the post-war western European experience of forgetting incommode truths was in many ways similar to the post communist ECE experience, ${ }^{56}$ it is perhaps the term 'coming to terms with the past', the English equivalent of the German 'Aufarbeitung' (coming to terms with), 'Aufklarung' (enlightenment, clarification) and 'Vergangenheitsbewältigung' (mastering the past), that probably describes the best the processes involved in this kind of closure. ${ }^{57}$ Although the horrors of the past which the West Germans had come to terms with were mostly different than those which the ECE citizens had come to, what probably unites the post-war West German's experience with that of the ECE space and make the German experience relevant to the ECE is the wholesale integration and of former officials of a totalitarian state in the administrative apparatus of new political regimes. ${ }^{58}$ In this respect, what Theodor Adorno wrote a decade and a half after the fall of Hitler about the refusal of the West Germans to face the terrible Nazi past and to come to terms with such past, is also relevant for the ECE space:

\begin{abstract}
" $[\mathrm{t}]$ he fact that fascism lives on, and that the much cited work of reprocessing the past has not yet succeeded, and has instead degenerated into its distorted image-empty, cold forgetting-is the result of the continued existence of the same objective conditions that brought about fascism in the first place... Now as then the economic order, and to a large extent the economic organization built upon it, together maintain a majority of people in a state of dependence on conditions which they have no control, thereby keeping this majority in a condition of political immaturity. If they want to live, they have no choice but to adapt themselves to the given circumstances, to conform; they have to put under erasure their status as autonomous subjects, which the idea of democracy appeals to; they can only maintain that status at the cost of renouncing it....Because reality doesn't provide the autonomy, or finally, the possible happiness that the concept of democracy actually promises, people are indifferent to democracy, where they don't secretly hate it......59
\end{abstract}

To sum up, closure with communism means several things. In the first place, it means the cessation of the total domination of society by the party state, with its accompanying long set of wrongs (such as the brutal repression, truth manipulation, pervasive and constant surveillance, and perpetual economic shortages and deprivation).

In the second place, it means a large scale healing, which involves the confrontation of the past crimes and abuses, the condemnation of criminal agents of the former regime, rehabilitations of the victims, and forgiveness.

In a third place, it means the reconstitution of a political and moral community endowed with citizens who act as rational actors. In practice this reconstitution implies the attribution of moral responsibility for past wrongdoing to communist agents and their temporary exclusion from the political community in the context of democratic transition.

Finally closure with communism means a long collective psycho-social and political process, in which the understanding of the collective and personal responsibility for the communism wrongs, and the forging of a new, democratic identity would play prominent roles.

\title{
3 A scorecard of closure with communism in the CEE
}

After we have seen the possible meanings of closure with communism, we could briefly asses the results of the first two decades of post-communist ECE transformations, in order to see what provoked the remarkable obsession with the communist past in 
post-communist societies. Because the 'coming to terms with the past' could be characterised as still ongoing in the region, we could leave apart the assessment of the results of this psycho-social and political process associated with 'closure', and turn our attention to the other meanings of the term.

Thus, in respect to the processes associated to the first meaning of closure with communism, we should observe that most of the objectives implied by this meaning were remarkably attained almost immediately after the fall of communism. Political freedom was obtained, the party-state ceased to exist, free elections were held, and the communist secret services were transformed and no longer operated in the brutal ways they did under communism. ${ }^{60}$ The only objective which was not successfully attained, at least in the first years after the fall of communism, was that of the economic deprivation and shortages characteristic of the socialist period. ${ }^{61}$ Moreover, during these early years the economic conditions actually worsened dramatically for a majority of populations of the ECE countries, in comparison with the socialist period. More importantly, however, if a majority of citizens in the ECE countries were becoming quickly the economic losers of transition, the members of a substratum of the former communist elites became with astonishing speed the big winners of such transition, on a scale not imaginable during the previous period. And it was in particular this double phenomenon of the pauperisation of the majority in parallel with the enrichment of a minority linked with the communism, which with the time came to surpass the great political achievements of the early years of post-communism, and cast a big shadow on the directions of the transformations. If the result of post-communist transformation was the enrichment of a few members of the former communist elite to the detriment of a majority, then where it was the rupture with the former regime and the closure with communism? Theorised early in the transitional period by authors such as Senyi Andras Koro or Jawdiga Staniszkis, ${ }^{62}$ and later enriched and amplified with subsequent contributions, ${ }^{63}$ this narrative of transformation challenged the dominant triumphant paradigms of post-communist transformations such as those related to the triumphal end of history. It also offered an expression to some of the fears and anxieties of the ECE populations, and a description to the socio-political processes ongoing in the region.

Accordingly to this narrative, the separation from communism and the great sociolegal transformations of the early post-communist years in the ECE did not lead automatically to closure with communism and to the apparition of a modern, rule of law-based society and state. Moreover, it allowed for the perpetuation of some of the fundamental structures of the communist state in parallel with distorted or incapacitated state institutions. ${ }^{64}$ As aptly remarked one of the observers of transformation:

\footnotetext{
"The disintegration of the ruling party in Easter Europe did not involve much of a change in the state apparatus...the state taken over by a Leninist party remained intact, now to be governed by parties elected by the domestic population" 65
}

Among the fundamental structures of the communist state perpetuated in the transitional period, it was for example the 'socialist enterprise.' This was later exploited or 'privatised' mostly by the members of the former communist technocracy, in conditions of a weak or debilitated post-socialist state, and supplied one of the building blocks of the post-communist societal arrangements. ${ }^{66}$ Arguably such dual process of survival and transformation of communist structures in post-communism contained at least two characteristics which enhanced an abstract demand for closure and for transitional justice 
measures. A first such characteristic was that the communist technocratic elite which initiated and benefited greatly from the post-socialist transformations could not reach its status in communism without a direct or indirect collaboration with the communist regime, and in some cases, with its secret police. ${ }^{67}$ To take the representative example for the communist technocracy of a director of a regional communist enterprise, in general it might be said that such technocrat could not be selected as director of such unit from a poll of equally qualified persons strictly on the basis of her qualifications, but had to show some political aptitudes to pursue better than others the line of the party. ${ }^{68}$ Similarly, such a director could not maintain her position, once selected, without the acceptance of the higher regional echelons of the communist party. As the communist system was highly hierarchical and oriented top down, the 'acceptance' means that the director was more 'able' than others to pursue at a minimum the 'plan' dictated by the party for the respective enterprise. Such 'ability' could take many forms, from the most severe one of making the life of all subordinates a hell in the pursuit of the plan, to the more elaborate and refined form of managerial control. Nevertheless, all such forms involved some sort of 'political' ability in addition to the director's technical ones, and a degree of collaboration with the higher echelons of the party, or with the communist secret police. ${ }^{69}$ Once the communism collapsed, however, this 'political ability' and degree of collaboration with the communist regime would suffice to insert a communist technocrat displaying them in a loosely defined exclusionary category of wrongdoers of the former regime, contained in the screening and lustration laws. Nonetheless, such loose category included in lustration laws would also have to overcome extraordinary difficulties in conceptualising in a manner acceptable in a democracy the condemnable 'political ability' of the communist directors and other technocrats, since this 'ability' was based on unwritten organisational codes of the communist parties. In part because of such difficulties, a category of wrongdoing which would cover the generic collaboration of the communist technocracy with the former regime never became the object of an administrative justice measure in the post communist ECE, or of any sort of political exclusion. ${ }^{70}$ While it would be mistaken to believe that this 'original sin' of collaboration of communist technocracy with the former regime was totally forgotten by the public, with the passing of years it could be expected a decay of emotions which would favour an abstract demand for administrative justice. Nevertheless, this did not happened, as a second characteristic of post-communist ECE transitions came into play. In brief, this characteristic consisted in the exploitation or transfer of the property of the former communist state to private hands by the former communist technocrats, in the context of widespread economic decline and worsening social conditions for a majority of citizens that characterised the first years of the ECE post-communist transitions. Happening on the spotlight of the press which covered a multitude of scandals related to such fraudulent transfers, the exploitation or transfer of state resources by the communist technocracy during the first years of transition was constantly associated with a perpetuation of the communist period's wrongdoing. And it therefore allowed for the continuation or enhancing of an abstract demand for administrative justice. ${ }^{71}$ This demand was aptly exploited by populists a decade and a half later, during the bitter political ECE fights of the 2005-2007. ${ }^{72}$

To conclude so far almost all the objectives associated to the first meaning of closure with communism, with the notable exception of the economic ones, were attained with remarkably speed after the fall of communism. However, the economic deprivation was not liquidated, but dramatically worsened for the majority of citizens of the former 
communist ECE, in parallel with a conservation or improvement of the economic status of the former communist technocracy. As the substantive moral guilt of the former communist technocrats was not beyond doubt, and important cases of enrichment of the former communists followed a pattern of praying on a weak and debilitated post communist state, the abstract demand for transitional justice measures and for closure with communism did not decrease but remained constant or increased. If this can be said with respect to the first meaning of closure, we should turn now to an assessment of accomplishments of objectives related to its second meaning.

As we have seen, the second meaning of closure relates to large scale healing realised by confrontation with the past, condemnation of criminal agents of the former regime, and rehabilitations of the victims and forgiveness. As we have also seen, in transitional justice theory such measures are important, as they allow to societies suffering from widespread and systematic political abuse to move forward toward democratic consolidation. However, in respect of this second meaning of closure, it should be said that closure with communism was at best partial. Announced with great fanfare immediately after the fall of communism, the condemnation of criminal agents of the communist regime quickly startled and then came to a halt all over region. ${ }^{73}$ Non-retroactivity of criminal law, impossibilities related to juridical proofs of criminal acts committed decades in the past, or numerous other legal niceties similar to those invoked by the Nurnberg trial defence were major obstacles encountered all over the region when criminal punishment was seek for the communist agents. In the rare instances when criminal communist agents were condemned, humanitarian considerations came often into play. So the condemnation of former communist agents for crimes committed during the communist grip on the ECE could be considered at best as fragmented and partial, and overall as unsuccessful. Moreover, polarised political representations of the communist past consisting in wholesale condemnation or essential acquittal led to a large discrepancy between the political representatives' declarations and lived experience, which was to stay with post-communist societies. In addition, the rehabilitation of the victims and reconciliation could be appreciated as a limited and partial success. ${ }^{74}$

The only domain were an overall success could be recorded was that of the official and public memory, where the communist official representations of the past suffered a mortal blow. Although the mushrooming of the Institutes of Memory in the region is not without perils, the impact of their prodigious activity is that the recent history of the ECE communist Europe is brought in line with what actually happened during the communist rule, and the gross mystifications of the communist regimes official history are gradually removed. $^{75}$

Finally, we should turn our attention to the third meaning of closure with communism, that of (re) constitution of a rational and moral democratic community. At its most basic level, this (re)constitution means complex operations related to the establishment of rapports with the former communist regime agents, according to statutes passed by the national legislatures. At the political level the establishment of such rapports then serves as foundational basis for the (re)constitution of a rational-moral democratic political community, while at the legal level it serves as basis for the application of administrative and civil law penalties. However, the establishments of rapports at the legal level are farther reaching than the application of administrative, labour or civil law penalties, although those are the most visible and discussed because of their immediate implications in the political and professional life of those sanctioned. 
While we will limit our discussion to the administrative and civil law sanctions, we will keep this distinction in mind. In order to understand what these establishments of rapports involve, and what problems plagued the post-communist ECE attempts to establish such rapports, we should provide in the following section a simple model of establishment of rapports with the agents of an authoritarian regime, and then apply it to the ECE post communist settings. Before we proceed with the model, we should add a terminological clarification.

In general, the (re) constitution of a rational and moral democratic community in transitions from authoritarian rule to democratic government, involves the liquidation of the legacies of the repressive immediate past. In the ECE post communist context, two such specific legacies were deemed important; that of the former communist parties, and that of their fearsome secret services. Further, two administrative procedures were considered important in dealing with such legacies: that of screening to ascertain the truth, and that of removal or impeachment. In a narrow sense, the administrative procedure of screening of persons for their possible involvement in communist secret police activities is what became to be known as 'lustration', while the administrative procedures consisting in removal or impeachment of such persons belonged to what was named 'de-communisation'.

In a larger sense, while 'de-communisation' could be defined as "exclusion of certain former communist officials from running in elections or from occupying public offices in the new regime", 'lustration' could be defined as "the screening of persons seeking (or occupying) certain positions for evidence of involvement with the communist regime (mainly with the secret police apparatus)". If not specified otherwise, we will employ 'lustration' in its narrow sense in what follows, and administrative justice as a synonym for 'lustration'.

Having clarified these terminological differences, we should return to the model of establishment of rapports with the agents of an authoritarian regime, and to its possible application in post-communist ECE settings.

\section{A general model of closure applied to the post-communist settings}

Among the students of the political transitions, it is widely acknowledged that once a Regime change occurs, the new regime could not start to work in a vacuum, but has to establish somehow a relationship with the actors and subjects of its predecessor regime. ${ }^{76}$

At the core of this relationship seems to stay a sort of double set of evaluations and judgments. The first set of evaluations and judgments is related to the former regimes institutions, structures and processes through which those former regimes interacted with the society. Such evaluations and judgments are made in the light of the values and goals of the new regime. The second set of evaluations and judgments of the former regime is related to the relationship of the individual to the political collective represented by the former regime. ${ }^{77}$ At the end of this complex process, a role of the individual in the political collective of the former regime is assessed, and a relationship with the new one established.

While the above establishment of relations is characteristic of every political change, including those occurring in democratic regimes as a result of elections, in the context of a political change which implies a rupture in political regimes the establishment of 
relationships become, as a rule, more radical than in ordinary political changes dictated by electoral cycles. ${ }^{78}$

During the course of history, a variety of modalities have been used to establish the more radical relationships formed after ruptures of political regimes, and their outcomes ranged from outright condemnation and extermination of former regime's actors and agents, to wholesale amnesties or even amnesias. ${ }^{79}$ Depending on the political circumstances in which the establishment of the relationships occurs, in the "worst of the times' actors and agents of the former regimes could expect instant extermination. ${ }^{80} \mathrm{In}$ 'better times' they could expect mild political purges and vetting, while in the 'best of the times', they could even indulge themselves with a prominent career in the institutions of the new regime. ${ }^{81}$

However, while in theory is recognised that arbitrary regimes may deal as they please with the former regime actors and subjects, it is further acknowledged that the democratic regimes are constrained in their actions by at least two factors. ${ }^{82}$

First, the democratic regimes should give reasons supporting the nature of this retrospective relationship. ${ }^{83}$

Second, if democratic regimes decide that they should deal with past injustices of former regimes' actors, they must deal with them through means and procedures consistent with constitutional standards of justice, such as the rule of law and equality before the law. ${ }^{84}$

Historically, in modern political transitions, as for example those occurring after the WWII, the two simultaneous conditions were considered to apply strictly just in the case of criminal punishment, and were more or less lessened with respect to political sanctions. ${ }^{85}$

Nonetheless, a more recent trend, and at least that of the East Central European regime change of 1989, was to consider the conditions applicable both to criminal punishment and to political sanctions. ${ }^{86}$

As a consequence, the (rule of) law, which mediates the criminal punishment in modern political transitions such as those occurring after the WWII became paramount in the newer trend, and moved to the fore in the process of articulation of political sanctions. The dealings of democratic regimes with the former regimes actors and subjects became thus subjects of 'transitional justice'.

To sum up, a democratic regime when taking over an arbitrary one has to establish a relationship with the actors of the former regime. In order to do so, it has to evaluate first the former regime institutions, structures and processes of interaction with the society, in light of its own value and goals, and then make a judgment of the actions of the former regime's actors.

However, it cannot evaluate and make judgments without giving reasons to support its evaluations and judgments, and could not decide to deal with the former regime actors without respecting means and procedures consistent with democratic standards of justice. And these requirements apply to both criminal punishment and political sanctions for past wrongs.

While the establishment of the relationships in case of criminal punishment may appear intuitively more controversial and complicated ${ }^{88}$ in reality it is the case of establishment of relationships which lead to political sanctions wrapped in the language of administrative and public law that is the most controversial and complicated. And this happens for a number of reasons, among which several are particularly important. The first one is that always the criminal punishment could target only a minority of actors and 
agents of the former regime, while the political and administrative sanctions target the many. ${ }^{89}$ In addition, once a decision to reach for criminal punishment is taken, the subject of the former regime is cleared from the decisional process of the new regime and the judicial institutions enter the stage, assisted in their work by a stable body of the law. ${ }^{90}$ Such stable body of law does not exist in the case of political and administrative sanctions, but has to be invented and attuned with the ever shifting goals of 'transitions'. In other words, while the criminal punishment decision seems to involve a onetime evaluation and judgment, after which the agent of the former regime is deferred to a more static process in which the judicial institutions and the law play a prominent role, the administrative political sanctions seem to resemble a more dynamic evaluation and judgment process, whose standards are more often changed and altered with the passing of time. But shifting standards, not well assisted by a coherent body of law, and with the potential to affect the many, contain in themselves the seeds of injustices and unequal treatment and raise additional difficulties in respect to their justification and coherence. Moreover, and in respect to their justification and coherence, the problems posed by administrative and political sanctions are further complicated by a collusion of intuitions and theoretical ideas of an earlier age of the humankind (that of the Enlightenment), with ideas from a later stage, that of ideologies dominating the twentieth century, As this collusion occurs in an undeveloped theoretical field, the field of reversion of a political system of the ideological age to a political system dominated by Enlightenment values, ${ }^{91}$ the administrative political sanctions for past wrong become complicated and controversial.

To an exterior observer this process of assessing, however complex and mined with potential controversies might be, could ultimately appear simple and involving only gathering of information and a chain of mental operations effectuated on this information. In a first step, for example, the new regime collects information in respect of the former regimes institutions, structures, processes and agents. Then, on a next step, it establishes the former regime's declared goals, modes of operations and the outcomes of its actions on the society as a large. Further, it compares these former regime goals and modes of operation with its own goals and its desired outcomes of state actions on the larger society.

Thereafter, the new regime 'decides' what wants to keep from older regime's institutions and what wants to change in order to better accomplish its goals. As institutions are manned by people, preservation or change in institutions means ultimately judgments about the elimination or preservation of the people, made by the people. If the former regime institutions, goals and procedures are deemed antithetical to the new regime ones, this will translate in judgments about the former regime actors and employees perspectives to adapt and function in a changed environment. ${ }^{92}$

Therefore, these actors and employees of the former regime would be evaluated in order to be seen how they could fit in the changed institutions. ${ }^{93}$

Finally, the new regime 'justifies' the decisions 'it' has reached and submits the justification, if necessary, to impartial third parties to the process, such as the courts. Although complex, this process should not be a complicated matter.

Whoever thinks so in rapport to post communist administrative justice is however mistaken. In the first place, the very concept of information regarding the vanished regime and its actors is in post communist ECE not a fixed one but is exceedingly elastic. $^{94}$ 
Firstly, accordingly and true to the Orwellian quote: "those who control the past will control the future", the process of information gathering became like Kundera's proverbial struggle of memory against forgetting a struggle of certain groups to tie information down against other groups who would keep its edges flexible, uncertain, and amorphous. In practise the most notable aspect of this struggle translated in post communist ECE settings in the long lasting controversies surrounding the communist secret police archives, and the access to personal files kept by these services. Although the issue of archives was prompted to the attention of the post-communist law makers by a wave of scandals related to the destruction of secret services files, ${ }^{95}$ it took more than six years to the country considered most aggressive in pursuing anti-communist policies to enact legislation regulating the status and access to such archives. ${ }^{96}$ And it would probably take more than two decades to the most lenient countries to enact similar legislation. In the meantime, the archives were privatised, as were the other assets of communist state, generating even more scandals. ${ }^{97}$

Moreover, while the decision to leave aside the files of communist parties and to 'focus' on the communist secret services was in itself controversial because it ignored the substantial guilt issues and missed the chance to compressively cross check the records, ${ }^{98}$ nobody bothered to observe that the destruction was in itself a criminal act accordingly to the communist regime statues, or to criminally prosecute the destructors of such files. Instead, the argument related to destruction was turned to its head. ${ }^{99}$

Secondly, the idea of a 'new regime', when taken in a larger sense of meaning, respectively that of a 'system of rule' than endures despite the fact that governments come and go, implies a sort of coherent structure linked by common shared goals of its participants. ${ }^{100}$ But in the post communist East Central Europe political landscape, participants as diverse and opposed in their experiences and political conviction as for example were in Romania Corneliu Coposu, ${ }^{101}$ and Ion Iliescu, ${ }^{102}$ always mixed in the political workings of the 'new regime.' So such a regime represented as a coherent initial 'system of rule' could hardly be imagined. ${ }^{103}$

Such a system was very much in the making in the beginning of the post-communist Period, as it still arguably is after two decades of 'transition', and its parts were there for grab. ${ }^{104}$

Thirdly, in the hectic and contradictory political environment of the first months or years after the fall of communism, clear goals or objectives of transformations were hardly to come. And this was visible even in the country which at the time was regarded as taking the most radical and farthest reaching lustration approach, Czechoslovakia, where the new leaders had no idea about the general direction in which the intelligence services should go or otherwise were not able to impose a minimum political oversight on such services until late in the transition. ${ }^{105}$

In the absence of clear goals, the establishment of relationships started to fluctuate accordingly to dubious political priorities of the moment, with the result of compromising the integrity of the whole process in the interim. How the integrity was compromised could be better understood if we compare the ECE post-communist processes with those taking place in Western Europe after the WWII. Thus, in most of the Western Europe after the WWII extensive lists of persons, "who did not behave as they should" during the war were used to establish administrative and civil law relationships. In addition, the wrapping in administrative language of political sanctions applied to these persons was based on uniform reversal of usual assumptions of non-guilt and non-retroactivity. 
Unlike the situations in Western Europe after the WWII, the establishment of relationships in post communist ECE involved a potential more extensive list of persons. However, the identity of such persons could never be fully determined with precision because the access to archives was lacking and because the criteria for inclusion in the list were the result of a political compromise and fluctuation. In the end 'the list' became a very limited one, in which persons were selected on highly disputable grounds, based on a cloudy cocktail of non-guilt or non-retroactivity principles mixed with collective guilt and retroactivity-based assumptions. As a result of these differences, while the coherent establishment of relationships and political punishments led after the WWII to enforcement which was harsh, uniformly or speedily applied, and short lasting, the establishment of relationships became in ECE a perpetual affair, slowly and selective applied and forever lasting. ${ }^{106}$

Fourthly, the establishment of relationships in post communist ECE was further complicated by the fact that a whole political generation active in the first two decades of transition was tainted by collaboration with the communist regime. As the state was the sole employer in the communist ECE there were no social mobility perspectives or career opportunities for ambitious persons outside the magic circle of communist state and party.

Unlike in Western Europe after the second war, or in Germany after unification, in the post communist ECE they were no political or economic elites untainted by collaboration. When dissidents existed and come to power in the region, not only that they lacked political experience, but were in general unable to constitute long lasting nuclei of outsiders of the communist regimes which could occupy the higher moral ground in the moral debates of the transitions. The former dissidents when in power also lacked a shared vision of the future or the past, and had very soon to include in their own political ranks ambitious persons of the former communist regime if they wished to save their own political future.

The price paid for the inherent political compromise reached with the former communist agents by the former dissidents' political movements was that such movements could not claim any longer clear boundaries for the establishment of relationships, even if they wanted to do so. In addition, as the opportunities of malfeasance multiplied or increased during a golden age of enrichment at the expense of the state which followed the fall of communism, the boundaries became more and more blurred, since 'magnificent reformers' and staunch anticommunists freely passed the line of corruption and greatly benefited of a continuous weakness of the state, which they tolerated and encouraged. ${ }^{107}$

Although the determination of boundaries or establishment of relationships was not, and perhaps is still not so difficult for a majority of the population of the ECE countries, as the communist past is still in the living memory, what became in time difficult and hard to accept for such populations were the skewed and ever shifting relationships and boundaries with the past proposed by a political class that became more and more homogeneous. Therefore, the narrow window of opportunity to radically reconstruct a democratic community in which the democratic institutions enjoy a high level of trust and legitimacy, offered by the spectacular fall of the communist regimes in the ECE, was probably lost for good because of the post-communist politics of establishment of reports with the communist regime agents. ${ }^{108}$ And the overall low levels of trust in the democratic institutions recorded less than a decade after the fall in the ECE, the low 
electoral turnaround of the later period, or the public perceptions of the new democratic institutions as inefficient and corrupt are all signs of this missed opportunity. ${ }^{109}$

Although it would be mistaken to believe that the implementation of administrative justice measures alone was sufficient to enhance the legitimacy and public trust in democratic institutions in the absence of other comprehensive legal and bureaucratic reforms, it could be also argued that 'lustration' was, nevertheless, one of the first such necessary measures to be taken in a succession of cumulative and mutually supporting steps, having as ultimate goals the enhancement of trust and legitimacy in democratic institutions, and the (re)constitution of a moral-rational political community. ${ }^{110}$

Done arbitrarily and hesitantly as it was done in post-communist ECE, lustration further compromised the efficiency of the other measures which could support lustration and exercise a cumulative effect on the reordering of the political community. Thus, frustration with lustration's results combined with the frustration provoked by other imperfect transitional justice measures, and enhanced the abstract demand for transitional justice.

In the end, however, when we asses such measures in the post-communist ECE world, perhaps we should not lose from the sight the long historical perspective and the complexity of the process. As the post war transitional experience of the Western Europe countries teaches us, even in better socio-political and economic circumstances than those of the post-communist ECE, there are no miraculous solutions for dealing with a repressive past. The collaboration with the Nazis, or the purges that followed after the WWII still haunt these nations collective memory many decades after the events. ${ }^{11}$

Although we perceive administrative justice from a legal point of view as a temporary device, its political-philosophical, and socio-psychological foundations collude with such legal perception. In exemplifying such collusion, we need not go further than to think that if the administrative justice measures are 'temporary' in the sense they should be applied or enacted not far in time from the fall of an authoritarian regime, their effects are permanent. At the same time it is true to say that the legislative elaboration and enactment of administrative justice (or other transitional justice) measures is not a perfect exercise, but an imperfect one, in which much is learned by trial and error.

Thus, administrative measures are perfected and enacted long after an authoritarian regime falls, as shown by the experience of the ECE post communist countries. These countries knew in the past decade a revival and enactment of administrative justice measures from a 'second generation', ${ }^{112}$ in which the similar experiences of other countries which underwent the process of democratisation arguably played a role. And in this respect Marek Safjan is probably right when it states that:

\footnotetext{
"Rather than wild justice or no justice at all, post-communist transitional justice policies have offered partial justice, and therefore constituted a politically feasible and morally defensible solution that was, nevertheless, far from being perfect." 113
}

\section{Conclusions}

As we have seen, closure with communism means several things, among which the cessation of the total domination of society by the party state, the end of perpetual economic shortages and deprivation, confrontation of the past crimes and abuses, the 
condemnation of criminal agents of the former regime and the reconstitution of a rational-moral political community are important.

The only place where the post-communist ECE countries registered a spectacular closure almost immediately after the fall of the communism was the cessation of the total domination of society by the party state. As a matter of fact, these countries became remarkably democrat and plural. However, this extraordinary success was shadowed by failures in other aspects of closing with communism.

For example, the partial and fragmented condemnation of criminal agents of the communist regime led to a large discrepancy between lived experience and the bombastic political (declarations of $\}$ criminalisation of the former regime.

More important, the prolonged and often impossible reconstitution of a rational-moral political community left important substrata of the former communist elites in position of command in the post-communist state and society.

Later, the members of such substrata were able to further weaken and exploit an already weakened post-communist state, contributing this way to a worsened economic deprivation of a majority of citizens, in the first years of post-communism.

Although by the end of the first decade most of the countries of the region recovered from the economic decline, the ways in which the huge transfers of state property in private hands enriched some of the members of the former communist elite were not forgotten as well as the hesitant ways in which the post-communist states dealt with their judiciaries, police forces, or established new institutions capable to enforce the law efficiently or to fight the economic criminality of the transition. In the end, it can be argued that all these imperfect closures increased an abstract demand for transitional justice and closure.

The multiple economic and political scandals, which shook the political landscape of the region, are in part a testimony of this impossible closure, inasmuch as it they are the result of an extreme polarisation and of the fight for resources of the post-communist state.

Gradually however, we also witnessed in the past decade a revival of administrative justice and enactment of administrative justice measures from a 'second generation'. Albeit the moment of a radical reconstitution of a rational-moral political community by means of administrative justice had passed, such administrative justice measures could still clarify disputed points of the recent past, and contribute to the reconstitution of a more democratic, rational-moral political community.

For the immediate future, we should not expect the administrative justice debates to stop entirely. As the longer historical perspective teaches us in respect to closure with a disputed past generated by a dictatorial or totalitarian regime's wrongs, there are no miraculous solutions for dealing with such an authoritarian or totalitarian regime's legacy, and the closure is a long and arduous process.

\section{Acknowledgements}

The author is grateful to István Pogány, George Meszaros, Lee Bridges, Ion Copoeru and two anonymous reviewers for their suggestions and comments on the earlier drafts of this article. All errors and deficiencies are of the author. 


\section{Notes}

1 In general the debate related to the communist past is centered on several recurring themes. One first such theme is related to the disclosure of the names of former communist secret services agents and collaborators Because in the most ECE space there was not sustained effort to make the communist secret services archives available to the public, political battles and scandals related to 'unauthorized' disclosures from such archives occurred with regularity during the last two decades. A second theme is related to the role of the communist secret services and member of the communist elites in what Venelin Ganev called 'preying' on the post-communist state. See generally Venelin I Ganev: Preying on the State. The Transformation of Bulgaria after 1989, Cornell University Press (2007). Although these themes are conceptually distinct, in the ECE discourses they often appear interrelated, and we could refer to them indistinctively when we mention the scandals. Although during the elections such debates became prominent, they also followed some sort of cyclical waves of political scandals. It is impossible to mention in this context all such periodic waves of scandals which shook the political stage of one country or another from the region in the past twenty years, for they were too many. But with the title of example, see Wiktor Osiatinsky: Agent Walesa? A grand scale provocation in Poland, 1 E. Eur. Const. Rev., 28 (1992) for and Marry Battiata: East Europe, Hunts for Reds. Washington Post, 18 December 1991, for an early such wave of the many in Poland. For the Czech Republic, see for example the earlier scandals documented by Kieran Williams in: Lustration as the Securitization of Democracy in Czechoslovakia and the Czech Republic, Journal of Communist Studies and Transition Politics, 19:4 (December 2003) at p.3, and the case of Jan Kavan, in Aviezer Tucker: Paranoids May be Prosecuted. Post-totalitarian Transitional Justice, in Jon Elster (Ed.): Retribution and Reparation in the Transition to Democracy, Cambridge University Press (2006), at p.198. For the Slovakian debate around the publishing of the names of former secret police officers, see Lucia Kubosova, Pandora's Box Online, in Transitions Online, 22 November 2004. For Bulgaria, see generally Venelin Ganev: Preying on the State. The Transformations of Bulgaria since 1989, Cornell University Press, 2007, or the more recent instance of the passions stirred up by a draft of a public law providing for the transfer of the Secret services archives and the revealing of all public figures who had collaborated with the secret police or had been victims of its repression in Kamelia Dimitrova, Spooked, Transitions Online, 19 January 2007. For Romania, see generally the scandals described by Denis Deletant in Deletant \& Williams, Security Intelligence Services in New Democracies, infra, EN_.

2 Even if the questions related to the direction of the present transformation, and in particular those related to the immorality of the actors of such scandals in communism and in transition are not always specifically formulated, they are, nevertheless, in the background of the discourses. If the communism fell and a regime change occurred, how could former agents of the fallen regime could play a prominent role in the new one? And what kind of new and democratic order could be one in which possible oppressors during communist times play the democrats? Evidently that all the scandals have less to do with proper criminal acts committed in the communist past by the persons involved in such scandals than with characteristics wrongdoings of such persons in the circumstances of the transitional period.

3 Such actors are normally the subjects of vetting and purges of the earlier transitional period. Lustration, vetting and purges of the communist regime personnel are all species of the 'administrative justice' proximal kind. For a definition of administrative justice, see for example: Ruti G. Teitel: Transitional Justice, Oxford University Press, 2000, at p.149 and subseq. On their turn, the vetting and purges measures are important topics on the debates related to administrative and retributive justice in transitional societies.

4 For those making such disclosures in journalistic or political discourses, it was irrelevant how such past of the politicians implied in scandals was related or relevant to the politicians' transitional misdeeds

5 After all, twenty years represents a period of time in which one could expect the emotions and interests which prompted the initial debate to drastically decay. For a detailed analysis of the role played by emotions in demands for transitional justice measures see generally Jon Elster, Chapter 8. Emotions, in Jon Elster: Closing the Books. Transitional Justice in Historical 
Perspective, Cambridge University Press, 2004. However, as Elster shows there are mechanisms which impede emotions to decay. For example, a "daily reminder of injustice prevents the normal decay of memory and emotions. Moreover, those who fail to improve their situation because they are stuck in the past are, as a result, constantly reminded of what they have lost". But for an argument related to the possible length of closure, see Luc Huyse, in Luc Huyse: Justice after transition. On the Choice Successor Elites Make in Dealing with the Past, Law \& Social Inquiry, Vol. 20, No. 1. (Winter, 1995), p.51 and subseq. We should revisit this issue, but for now suffice it to observe that the first years after the fall of communism contained sufficient daily injustices for the citizens of Central Eastern Europe countries. As the economic hardship and rampant inequality became soon the rule in the region, it was easier and convenient for the incipient political class to blame the failures of economic policies or the absences of political programmes on persons, especially when the absence of personnel changes in the new polities was so widespread. And with the time, the focus on persons and not on institutions or policies became so conveniently embedded in the new political game that it was used not only by the anticommunist politicians but also by politicians belonging to the communist successor parties.

6 The Judges of the European Court of Human Rights themselves appeared to be sensitive to the need to impose punitive administrative measures against former agents of the communist regimes in the initial transitional period. See for example the wording of the Grand Chamber Judgment of 16 March 2006 in the case of Ždanoka v. Latvia (Application no. 58278/00): "It is commonly accepted that certain restrictions may be necessary in newly established and vulnerable democratic regimes (just as the requirement of proportionality is), and this approach has been developed by the Court in addressing a number of clearly defined questions" and: "We have no difficulties in accepting the legitimacy of a punitive measure, since we cannot exclude the possibility that the restriction in issue could have been justified and proportionate during the first few years after the restoration of Latvia's independence."

7 As a matter of fact, what was reversed by the legislation enacted or proposed to be enacted in the second decade of transformation was the closure of the communist secret police archives. The partial opening of the archives was combined with introduction of legislation requiring the political candidates to declare their former reports with the secret police. This mechanism is well described by Monica Nalepa: To Punish the Guilty and Protect the Innocent. Comparing Truth Revelation Procedures, Journal of Theoretical Politics, Vol. 20, No. 2, (2008), at pp.221-245.

8 A brief analysis of various meanings of the term 'closure' reveals why is so difficult to close. Thus, accordingly to Prof. Paul Humphrey's 'closure' entry in The Oxford Companion to Philosophy: "As used in philosophy, a domain of objects is closed with respect to some relation just in case the relation never holds between sets of objects some of which are inside the domain and some outside. One of the most common applications is to causal closure: physicalists hold that physical events are closed under causation - nothing physical is caused by anything non-physical such as mental events, nor do physical phenomena cause mental phenomena. In logic, a domain is closed under a set of operations if the result of applying any of those operations to a member of the domain results in something that is itself in the domain." (for a detailed discussion of the 'Epistemic Closure Principle' see Steven Luper's similar entry in the Stanford Encyclopedia of Philosophy). Heuristically, this definition suggests that the impossible 'closure' of communism might have to do with the ways in which sets of mental 'objects' (traits, characteristics, concepts) which are inside the domain (communism) are attempted to be closed by the applications of sets of mental object that are 'outside' the domain (liberalism, for example). Although Gunther Teubner's twelfth camel of law might reformulate the domains and help the solving of the puzzle as it did in the old Bedouin story, the contribution of law in solving the problem is questionable. (See Gunther Teubner: Alienating Justice: On the surplus value of the twelfth camel, in David Nelken and Jirí Pribán (Eds.), Law's New Boundaries: Consequences of Legal Autopoiesis, Ashgate, Aldershot 2001, pp.21-44). But the philosophical meaning of closure is not the only one. From a sociological standpoint, John Scott and Gordon Marshall provide us a definition of closure (social closure) in Oxford Dictionary of Sociology as a concept emerged from Weber's thought "as an alternative to Marxist theories of inequality"... "Weber saw closure as 
being one of the means by which commercial and property classes moved along the continuum of legitimating and reproducing their life-chances in the direction of social class formation. Later exponents of this view saw closure as the basis of all inequality, be it that of material reward, status honor including ethnicity, caste, and even the nomenclature system of communist regimes.... Processes of social closure involve marginalization (or exclusion), on the one hand, and incorporation (inclusion) on the other..." Thus, accordingly to the social closure understanding, a closure with the communist past might meant two different things; an exclusion of the former communist elites, or a process of transformation of older communist closure in a different kind of closure. And, as we will see, both processes were theorized in the scholarship regarding post-communist transformations. In additions to the above, closure has also a psychological meaning. Brought around 1910 by the Gestalt school of therapy in Germany into psychology to describe the way scattered and troubling feelings can resolve themselves in coherent and stable mental patterns, it came to means coming to terms emotionally with psychological trauma. As the communism was brought and exercised by violence, closure might mean in respect to communism the appropriate process of confronting and process that past experience. See generally Jacob D. Lindy and Robert Jay Lifton (Eds.) Beyond Invisible Walls: The Psychological Legacy of Soviet Trauma, East European Therapists and Their Patients, Routledge, 2001; Neil J. Kritz, Coming to terms with atrocities: A review of accountability mechanism for mass violations of human rights, 59-AUT Law \& Contemp. Probs, 127 (1996). Finally, in the common language, closure means "closing down, shutting down, winding up, cessation of operations, cessation, termination, finish, and conclusion"'(see The Oxford American Thesaurus of Current English. Ed. Christine A. Lindberg. Oxford University Press, 1999). In post-communist transformations, this will imply the closing and shutting down of the features of the party state polity, as the dominant role of the party, the centralized operation of bureaucracy, the surveillance of the communist political police, and soon. To simplify our discussion, we will often assume this meaning as representing 'closure' with the communist past.

9 Monica Nalepa: To Punish the Guilty and Protect the Innocent, supra, End Note 7, and Nalepa: Skeletons in the Closet, infra End Note.

10 Id.

11 See e.g. Cath Collins: Post-Transitional Justice. Human Rights Trials in Chile and El Salvador. Pennsylvania State University Press, 2011. Collins provides a useful theoretical framework which in our view could be extended to the post-communist space. Unfortunately, given our limitations of space, we cannot discuss in more detail here this framework.

12 The author is grateful to one of the anonymous reviewers for this pointer.

13 See e.g., Pablo de Greiff (Ed.): The Handbook of Reparations, Oxford University Press, 2006 and Brandon Hamber: Transforming Societies after Political Violence Truth, Reconciliation, and Mental Health, Springer Dordrecht, Heidelberg-London-New York, 2009.

14 Brandon Hamber, id.

15 For a definition of 'lustration' and its distinctive feature in rapport with de-communization see Maria Los: Lustration and Truth Claims: Unfinished Revolutions in Central Europe, Law \& Social Inquiry, Vol. 20, No. 1. (Winter, 1995), pp.117-161, at p.121. Usually, when used in the traditional transitional justice literature, 'closure' means a kind of discontinuity with the former regime policies, institutions, goals and personnel, discontinuity enforced by legislation. In most of transitional studies discontinuity and legislation are sometimes analyzed separately, and sometimes together. When they are analyzed separately, the analysis purports to establish the difference between the actual discontinuity or legislation and some normative variant of discontinuity or legislation adopted by the author. When they are analyzed together as is usually done in impact studies, the legislation is evaluated in respect to discontinuities it produced, albeit more complicated models in which discontinuity and legislation are simultaneously evaluated from a normative standpoint could be found in the literature. Although we share the idea of dominant paradigm in respect to the discontinuity, we advance a different view in respect to the purpose of one of the main transitional devices used for closure, vetting and purges. 
16 For a variant of this view see Kieran Williams (2003): Lustration as the Securitization of Democracy in Czechoslovakia and the Czech Republic, Journal of Communist Studies and Transition Politics, Vol. 19, No. 4, (2003), at pp.1-24.

17 One of the major aspects of post-communist 'transitions' was the divesture of the state from administering the immense domain of the state, characteristic to communist societies. Such divesture was realized mainly by 'privatization' and 'restitution', legal devices which could be explained as 'distributive justice' measures. In the condition of such divesture of the state from administration of communist property, accomplished by transfers of property realized by 'privatization' or 'restitution', the former managers of socialist property, not replaced as administrators of such property, could manipulate the new legislation related to privatization and restitution in order to carve for themselves a big share of resources transferred from the state to private entities (by 'privatization' or 'restitution'). In other words, these former communist managers belonging to the technocratic communist elite could be a major recipient of the distributive policies followed in the post-communist space. However, 'lustration' targeted among other communist regime actors, such technocratic communist elites. If 'lustration' has as effect the replacement of such elites before 'privatization' or 'restitution' occurs, then such elites could not benefit the 'distribution' operated by the post-communist regimes by way of privatization or restitution. And in this regard we speak about the potential effects of lustration to affect the major 'distribution' operated by the post-communist regimes. Given the limitation of space, we cannot discuss here in any depth this issue, but a more in depth analysis is provided in our forthcoming doctoral thesis with the University of Warwick. For similar limitation of space, we cannot cite here all the relevant literature on 'nomenclature' privatizations or the ways in which these former elites benefit the 'distributive' policies followed by the post communist states. Suffice it to indicate with the title of example David Stark: Recombinant Property in East European Capitalism, The American Journal of Sociology, 101: 4 (Jan., 1996), pp.993-1027; David Stark and Lazlo Bruszt: Postsocialist Pathways: Transforming Politics and Property in East Central Europe, Cambridge University Press, 1998 for different ways in which the technocratic communist elites were able to manipulate the post-communist legal environments, or Katherine Verdery: Katherine Verdery: The Elasticity of Land: Problems of Property Restitution in Transylvania, in Verdery: What Was Socialism and What Comes Next, Princeton University Press, 1996, pp.133-134; and Katherine Verdery, The Vanishing Hectare: Property and Value in Postsocialist Transylvania, Ithaca, NY: Cornell University Press, 2003, , for the ways in which 'restitution' benefited the local technocratic communist elites entrusted with its implementation, or Katherine Verdery and Caroline Humphrey (Eds.): Property in Question, Value Transformation in the Global Economy, Berg, 2004, for theorization of post-communist transformation of property.

18 For the clear delimitation between the 'them'-communist apparatchiks, managers, and secret police agents and 'the rest of us', which prolonged after the fall of communism, see Katherine Verdery: What was Socialism and what comes next, Princeton University Press, 1996.

19 For a discussion of transitional justice measures such as lustration adopted for strategic reasons, see Monika Nalepa: Skeletons in the Closet: Transitional Justice in the Post-Communist World, forthcoming book proposal, on line at http://web.mit.edu/polisci/research/Nalepa_Chapter1-1.pdf (last visited May 2010).

20 This is not to say that some sort of prosecution of criminal agents of the former communist regimes was not undertaken in the region after the first decade, or that political debates related to compensation due to the victims of the dictatorial regimes of the region disappeared totally from the Parliaments agenda. It is just to say that the salience decreased dramatically in intensity, in comparison with the first post-communist years. For a comprehensive study of the various transitional justice efforts undertook by the countries of the region see, e.g., Carlos Closa Montero (Ed.): Study on how the memory of crimes committed by totalitarian regimes in Europe is dealt with in the Member States, submitted to the European Commission as provided by the European Council Framework Decision "on combating certain forms and expressions of racism and xenophobia by means of criminal law", on line at: $\mathrm{http} / / /$ ec.europa.eu/justice/doc centre/rights/studies/docs/memory of crimes en.pdf

(thereafter Montero Study), last visited October 2011. Montero study is focused on the 'memory' of the crimes of the totalitarian regimes in Europe and offers the following vision of 
transitional justice methods in the preamble of the report that "The aim of the study is to provide a factual overview of the different methods employed by Member States to deal with the memory of the crimes committed by totalitarian regimes. In this regard, the study covers the full range of measures that in contemporary academic literature have come to be labelled as 'transitional justice mechanisms', i.e. a broader range of methods utilized to respond to the memory of the crimes in focus. On this account, memorialisation efforts constitute one category of measures. Other measures include (1) criminal investigations and prosecutions; (2) truth-seeking mechanisms (such as truth commission); (3) reparations for victims; and (4) guarantees of non-repetition and institutional reform." Montero Study, op. cit, at p.13.

21 The term 'really existing socialism' is an adaptation of Rudolph Bahro's 'actually existing socialism', in his The Alternative in Eastern Europe, London, Verso, 1978.

22 The literature documenting the communist takeover and its implications is too voluminous and growing to enable us to indicate even tentatively the most important titles, albeit one of the great classic titles on the subject which deserves a mention here is Hugh Seton Watson: The East European Revolution, Methuen \& Co. Ltd. London, 1950. However, we should note here several features of the communist repression in Central and Eastern Europe. First, the greatest number of victims of the ECE communist regimes was made during the so-called Stalinist period, from 1945 until after the death of the Stalin, in 1953. The sheer number of people tortured, killed, or with the future destroyed by cruel and inhumane methods applied by the communist state repression 'organs' during this period and shortly afterwards is staggering, albeit just tentative figures could be advanced in the literature, and it is doubtful if the real number could be ever advanced. For one of the rare attempts to estimate the number of victims see R.J. Rummel, Death by Government, Transaction Publishers, New Brunswick, N.J.: 1994. Rummel, who spent a great lot of time attempting to document the number of victims of various totalitarian regimes in the XX century, felt even the need to coin a new term 'democide' in order to suggest the mind blowing number of victims resulted in the XX century as from state repression or criminal activities of authoritarian or totalitarian states. Second, the repression was not equal in all the countries in the region, and varied across the time in each country. Each wave of popular revolt which occurred in one country, as for example the GDR uprising in 1953, or the Hungarian Revolution in 1956, the Polish revolts in the fifties or sixties, the Prague's Spring in 1968, the Romanian Miners revolt in Valea Jiului in 77, the Polish revolts in the 70's, or the Solidarity movement in the eighties could provoke bloody repressions in the country in which it occurred, but with the exception of a state of higher alert of the other communist countries security services, of their national armies or of the Soviet forces eventually stationed in these countries, lesser repressions in the other countries of the Socialist bloc occurred. And mass repression was avoided especially when the society of these countries did not revolt en masse or otherwise followed the example of their 'socialist brothers' from the country in which the revolt first occurred, as was in general the case. Third, the repression varied across the time in each country, following a general trend to diminish after the fifties. With perhaps the exception of Romania, Albania, and Poland during the eighties, which because of particular circumstances became more repressive while the others attempt to liberalize their regimes, the general trend in the seventies and eighties was towards a relaxation of the regime, albeit truly 'relaxed' was probably only Hungary. Of course, this does not imply that any of the communist regimes of the region lost significantly its capacity to repress with brutality any revolt, if it desired to do so; it only implies that the large scale brutal repression of the forties and early fifties ceased to be the model. So, given the various waves of repression several generations of victims in these countries could be encountered, with a major proportion of victims given everywhere by the members of the generation who fall under the savage repression of the Stalinist era, but with significant differences among the communist countries of the region between the younger generations of victims, function of particular wave of repression in each country. Thus, we could expect for example to see in Hungary, in comparison with the Czech Republic, victims who are a decade older than the Czech ones, given the fact that the Hungarian revolution and the repression which followed occurred 12 years earlier than the Czechoslovak Prague's Spring. This fact is perhaps not without any relevance, in respect to the victims' agendas or even the possibility to prosecute the perpetrators, albeit we have numerous other variables which influence the possibility of prosecution, and therefore differences between prosecutorial results among each country. 
Nevertheless, the number of former agents of communist 'security' services and repressive apparatuses (including the police, paramilitary or prosecutorial services), or communist bosses responsible for the repressions condemned for their participation in repression is dim in all the countries of the region, including the former GDR, where energetic prosecution was contemplated and undertaken during the early nineties. Therefore, Monica Nalepa's argument about Poland and Hungary could be somewhat extended to the whole region, as we will show later in the article: "In countries such as Poland or Hungary, the first few years of the transition aftermath brought little transitional justice activity - some trials were initiated here and there, but overall, there was nothing spectacular" (see Monika Nalepa op.cit). And in respect to Hungary and Poland themselves, the following decade after the fall of communism did not bring much. Thus, for Hungary, where the events of 1956 produced high passions, the national level prosecutor charged the perpetrators of seven of the almost forty investigated so called salvo-incidents, instances when the military forces kept up sustained fire in order to break up demonstration, killing and wounding citizens, which occurred in that year. In one case, three of the accused received definitive convictions. See Jorg Arnold: - Criminal law as a reaction to system crimes (Criminal Law Vergangenheitspolitik and its forms of transitions) in Jerzy W. Borejsza and Klaus Ziemer (Eds.) Totalitarianism and Authoritarianism in Europe: Short and Long-term Perspectives, Berghahn Books, 2006, at 404. In Poland, by December 1997, the Commission for the prosecution of crimes against the 'Polish nation' had initiated investigation in a little more than 1,000 cases of criminal acts committed during the Stalinist era. From those investigations, it concluded 693 cases, recommending in about half of them, respectively 240 cases, that public persecution should start, and making motions in 250 cases for the discharge of proceedings due to the death of the accused. Jorg Arnold, id. Accordingly to the statistical data "concerning activities of the Branch Commissions for the Prosecution of Crimes against the Polish Nation" published on line by the Polish Institute of National Remembrance (available on line at: http://www.ipn.gov.pl/wai/en/21/54/, last visited March 2009), albeit it opened approximately 900 new inquiries on alleged communist crimes after 2001, and interrogated more than ten thousands witnesses and suspects, the Branch could not to bring more than 20 indictments. This does not necessarily means that a court sentenced the persons indicted by the Branch, although from the data published by the Branch it is not possible to know how many indictments resulted in convictions. One of the few successful prosecutions of communist era crimes is described in the US State Department 2008 Human Rights Report for Poland, and resulted in the condemnation of 15 Communist-era police officers to prison terms from two to eleven years for their guilt in killing and wounding striking coal miners during an incident in 1981.

23 See generally Katherine Verdery: Theorizing Socialism: A prologue to the 'Transition', American Ethnologist 18:3 (representations of Europe: transforming state, society, and identity) (August 1991), pp.419-439; Ivan T. Berendt: The closed society in Stalinist state after 1948 (especially: Legal framework, structure, and characteristics of the party-state, and in general; Party hierarchy and discipline, and The legal system of terror and beyond) in Ivan T. Berendt: Central and Eastern Europe 1944-1993. Detour from the periphery to the periphery, Cambridge University Press, 1996 pp.42-79. For the major distinctions between Nazism and communism see Berendt, above, at pp.53-55, and also Erich Hobsbawm: Real Socialism, in the Ages of Extremes, in Eric Hobsbawm: Short XX century, Pimlico, 1997, at p.394. Perhaps Katherine Verdery's creative adaptation of a later version of the totalitarian paradigm and her nuanced and thick description of 'real existing socialism' is one of the best analytical introductions to the main characteristics of this system in the ECE. For the differences between the different paradigms adopted for the analysis of the Soviet type systems, their origins and intellectual underpinnings, see Seymour Martin Lipset and Gyorgy Bence, infra, EN 13. For a history of ideas which led to the Soviet model imported in ECE see Alain Besançon: Les Origines Intellectuelles du Léninisme, Calmann-Levy, 1977, and for several implications of the model see Andre Glucksmann: La Cuisinière et le Mangeur D'hommes. Essais sur les rapports entre l'Etat, le marxisme et les camps de concentration, Editions du Seuil, 1975. Nowadays it is perhaps understandable why Besançon or Glucksmann ideas or the late eighties adaptations of the totalitarian model are overlooked, while newer ideas, sometimes devoid of content when applied rigidly to post-communist context, such as 'globalism', 'reform', 'institutions' or 'corruption' strive to make a paradigm for the 
post-communist changes. But the study of the post-communist transformations and in particular the understanding of the 'transitional justice' measures taken in respect to the communist heritage makes little sense outside the understanding of the main features of the socialist system, and the insights provided by such authors did not alter with the passing of time. What was important in the beginning, and arguably still is, were the most unpleasant characteristics of the 'real existing socialism'. And what is perceived now with displeasure in respect to post-communist heritage, and called, for example, 'global' networks of 'organized crime', or 'terrorism', had the nuclei already in place in the 90's, as a result of decades old of cold war efforts of espionage and counter espionage conducted by the Soviets and the ECE satellites. What changed is only the perceived abrupt retreat of the state from these operations, as a result of what Maria Los and Andrzej Zybertowicz termed the privatization of police state. We should briefly return however to these themes later.

24 For one of the best description of the instrumentalist-formalist conception of the law in ECE and its practical implication in transformations, see Andras Sajo: New Legalism in East Central Europe: Law as an Instrument of Social Transformation, Journal of Law and Society (1990) Vol. 17, No. 3, pp.329-344. Some of the ideas expressed by Sajo were duplicated for a Polish context by the human rights activist Ewa Letowska "Poland is not a state of law [Rechtstaat] and it will not be for a very long time. The law is still treated in an expedient way, as a tool of the existing politics or policies... The subordination of law to politics still exists although it had been officially rejected...", as cited by Berendt, supra, at p.314. For the origins of these instrumentalist-formalist conceptions on law introduced by the communists after the WWII see Berendt, op. cit, at pp.50-57. For the relationship between the truth and ideology, see for example Besançon, First chapter: Ideology, and chapter sixteen: The Empire of the False, in Besancon, Les Origines..., supra, and for the 'practical' results of the application of the ideology on truth, see Glucksmann: Part II. The worst lie of the century: USSR, in Glucksmann, La Cuisinière ..., op.cit.

Berendt, id.

That of its introduction in the ECE with the helping hand provided by Stalin.

See Tony Judt: Chapter 6: Into the whirlwind, in Tony Judt: Postwar. A history of Europe since 1945, Pimlico edition, London, at pp.129-196, and Berendt, supra. Accordingly to Judt: "Opportunities abounded, particularly at the lower lungs of the ladder and in government employ: there were jobs to be had, apartments to be occupied at subsidized rents, places in schools reserved for the children of workers and closed to the children of bourgeoisie. Competence mattered less than political reliability, employment was guaranteed, and the burgeoning Communist bureaucracy sought out reliable men and women from everything from block organizer to police interrogator". Judt at p.176. In other words: "The revolution of state socialism was, in a way, the revolution of mediocrity", in Berend, op. cit at p.55. Afterwards, the social mobility decreased, and in respect to the elites the patterns of an earlier period ironically returned in late socialism. In the words of the late Joseph Rothschild: "Who composed this political elite? Not the direct genealogical descendants of the interwar bureaucratic-intelligentsia-gentry elite. That elite was toppled, or at least swamped, by the upheavals of World War II and the massive, rapid Stalinist injection during the post-war period of veteran Communist cadres and levies of newly radicalized 'red-diploma" workers and peasants into the corridors of power. Yet the old, ousted elite took its 'Hegelian revenge' ("mankind makes its history behind its own back") by transmitting many of its styles, traits, and values to these usurpers, who, in turn, made sure that their own children, rather than another generation of upstart workers and peasants, would inherit their positions and privileges. Thus the corridors of power became blocked to authentic workers and peasants, just as they were during the interwar era, while a highly politicized party and state bureaucracy mimicked the gentry-intelligentsia pretensions of the interwar bureaucracy, aped its smugness, and replicated its nepotism, reigns, and rules. The socially closed nature of this self-protecting and self replicating elite was redoubled by the prevailing patterns of access to higher education. All the ideological rhetoric supposedly favouring the children of manual workers and peasants indeed became mere rhetoric, as the proportion of university students from these 'toiler' backgrounds declined. Not surprisingly, "the moral and psychological gap of the 1930s between the elite and the masses also replicated itself in the 1980s." Joseph Rothschild and 
Nancy M. Wingfield: Return to Diversity. A Political History of East Central Europe Since World War II, Third Edition, Oxford University Press, New York and Oxford, 2000, at p.224. The differences in social mobility and stratification between socialist states and western capitalist states, and among socialist states themselves are also documented and theorized (Parkin, 1969, 1971; Giddens, 1973; Lane, 1982; Konrad \& I. Szelényi, 1979; Walder, 1985; Jowitt, 1992). For more recent research, see for example West Eric Hanley, A Party of Workers or a Party of Intellectuals? Recruitment into Eastern European Communist Parties, 1945-1988, Social Forces, Vol. 81, No. 4 (June 2003), pp.1073-1105.

28 Berendt, id. It also made supportable the communist economic system, in which the salaries were kept artificially at incredible lower levels in comparison with the world market. Berendt, supra.

29 These economic and political wrongs are just a partial list. For a more detailed and thick description see István Pogány's 'Introduction', in István Pogány: Europe in Change. Righting wrongs in Eastern Europe, Manchester University Press, 1997, at p.1 and subseq.

30 As István Pogány observed: "Frequently, perceptions in Central and Eastern Europe as to wrongs are the product of a mixture of personal as well as ideological and cultural consideration". Pogány, id., p.10. We should also keep in mind that closure has a more fluid meaning in states' political regimes transformations, as some of the vital functions of the state have still to be exercised. So closure means the cessation of some operations, but also a transformation of the vital operations in something done accordingly to different values and goals of the new regime. For example, if we take the case of the communist secret police, closure means cessation of the operations of these institutions against political opponents, and the redefinition of goals to be achieved by intelligence activities. Therefore, lato sensu, closure also means a transformation of the goals, values and operations of such institutions, as much as it means cessation or termination of many of the former activities.

31 We should keep in mind that closure has a more fluid meaning in transformation, as some of the vital functions of the state have still to be exercised. So closure means the cessation of some operations, but also a transformation of the vital operations in something done accordingly to different values and goals of the new regime. For example, if we take the case of the communist secret police, closure means cessation of the operations of these institutions against political opponents, and the redefinition of goals to be achieved by intelligence activities. So closure means also a transformation of the goals, values and operations of such institutions, as much as it means cessation or termination of many of the former activities.

32 Similarly, when the reformist communist party leaders entered the talks with the opposition, or staged the removal of fossilized leaders from the top positions, they did it only because they perceived that the communist parties' positions were untenable as a result of mass protests and the reluctance of the repression forces to intervene. The communist reformer probably knew better than anyone else in the region that the street protests were just the iceberg of a profound unpopularity of the communist government and the speed with which the communist regime disappeared in the ECE demonstrate how unpopular these regimes were, and how fragile their grip on society, in the absence of repression.

33 'Closure' in this psychological context mean a situation where the trauma is no longer seen as unfinished business, requiring, for instance a compulsion to take revenge. Grief and loss no longer plague the individual consciously or unconsciously, and the victim lives not in a state somewhere between denial and obsession, where the loss is to a large degree accepted and incorporated into the functioning of everyday life.

34 Neil J. Kritz: Coming to terms..., op. cit., at p.128.

35 Kritz, id.

36 Such as grieving, accountability, forgiveness, and rehabilitation of victims and perpetrators. Kritz, id.

37 Kritz, id.

38 The widespread violence should not be understood just as physical violence, such as torture or murder, but in a larger sense, which includes psychological violence as well. In the 45 years of communist rule in the ECE, the violence as the main mean to govern society, transgressed 
from large scale physical violence of the early years to the insidious, mostly psychological violence of the final years. But the essence of communist grip on power remained the same, and was based ultimately on the resort to violence.

39 For the Leninist conceptions on the political community see Besançon, Chapter 13: Political Leninism, in Besançon, Les Origines..., supra. Besançon attaches this conception to Lenin's exceptional Manichaeism. For Lenin the society was polarized in classes, which could not form a political community. Per Besançon: "There is no common good and no friendship." There is just hate and war, and "The scope of politics is to destroy the adversary." The space does not allow treating otherwise than by a succinct mention the monumental trilogy edited by Hans Maier on the links between totalitarian and religious systems. See Hans Maier (Jodi Bruhn transl.):Totalitarianism and Political Religions, Volume 1-3 (vol. 2 with Michael Schafer) Concepts for the comparison of dictatorships, Routledge, 1996-2003

40 We will follow the description and insights provided by Besançon, who in our view provided an excellent explanation of several paradoxes of the Leninist political conceptions which were later implemented in the USSR and the ECE, in particular its problematic relation with the reality.

41 Besançon, id.

42 This double nature of truth in communism possesses almost insurmountable problems in the transitions to democratic societies. For an interesting discussion on the communist truth from a Romanian perspective, and on the complex relationship between truth, morals and lustration, topics we will explore in the following sections, see Mihaela Miroiu's lecture at the Indiana University: Morality in Politics, or the Politics of Morality? 'Neo-Purification' in Romania, on line at http://www.indiana.edu/ ias/plecture/text/mihaela_lecture.pdf (last visited May 2009).

43 For the magic role of the ideological discourse, and for the distortion of the reality, see Besançon, Chapter 16, The intellectual origins, supra. This large scale manipulation of truth made dissidents as Vaclav Havel to point to the absolute necessity to 'live within the truth' as a main mean of opposing the regime. See Vaclav Havel, The Power of the Powerless, in Open Letters. Selected writings, 1965-1990 (Ed.) Paul Wilson, New York, Random House, Vintage Books, 1992, at pp.147-148.

44 It might be argued, however, that in the communist regime late years the Michaels' Iron Rule of Oligarchy could be a better explanation for how the fossilized system worked, than the Besançon analysis of the earlier, Leninist phase. But this is a debated point, and the visions among the western and eastern scholars often diverged on this issue. As the late Seymour Martin Lipsett informs us (see Lipsett, supra, EN 14) there was widespread dissatisfaction among the western sovietologist with the pure totalitarian model in the seventies and eighties and an attempt to bring the soviet system analysis in line with more contemporary social sciences preoccupations derived from the developed west. On the other hand, the eastern dissidents returned in their analyses of the system during the same period to the totalitarian model. While the transformations of the Soviet and its ECE satellites system should be acknowledged, and the bureaucratic fossilization and the lost of ideological drive should be recognized, we think that is should be mistaken to believe that the initial features described so aptly by Besançon were abandoned in the last years of the communist rule. What perhaps disappeared was the early impetus to totally change society by force, to bring it in line with the ideological version, as the regime become more defensive. But as Ceausescu case shows in Romania, this disappearance of impetus was a variable of the local factors and personalities of the party bosses, and not a sign that the Leninist justifications described by Besançon vanished from the communist parties system of thought.

45 See for example John R. Pottenger: The political theory of liberation theology: toward a reconvergence of social values and social science, SUNY Press, 1989. The following observation of Pottenger: “.... [A] close relationship exists between theories of human nature and theories of political regimes. In the modern era, political theorist have attempted to answer the essential question of what kind of political regime is legitimate by beginning with an analysis of human nature" (Pottenger, supra, at pag 165), is important for the understanding of the deep and major difference between the Leninist political theory and the political theory of the democracy. 
46 In general the rationality could not be divided conveniently, so you could claim that in the past you were irrational but now you are. You have it, or you have not. Evidently that in the real post-communist world there was not so simple to introduce rationality this way and to link it to morality and truth. Because an administrative exclusion from the democratic community had serious consequences as it was followed by civil and professional sanctions, major debates and political battles were fought around the issues of who should be excluded and for what, and in these battles of words the major controversies of the field of moral epistemology were imported, together with the controversies surrounding moral dilemmas and moral principles, as they should. Nonetheless, these acrimonious debates have a positive side, in the measure they forced the people to think about the morality, rationality and truth relations with both communism and the new democratic polities.

47 The space does not allow us to further explore the philosophical justifications of punishment and the relations between the reconstitution of a moral and democratic political community and punishment. A good restatement on punishment justification in a democratic society is provided by Nicola Lacey: State Punishment. Political Principles and Community Values, Routledge International Library of Philosophy, Routledge, London \& New York, 1988.

48 We should revisit this issue in the last section, when we apply a model of closure to administrative justice in post-communist settings. Here we only note that this tendency applies in general to all transitions from authoritarian rule, not only to these applying to the ECE post-communist transitions.

49 For a general description of these events, see Tom Gallagher: Theft of a Nation. Romania since Communism, Hurst \& Co, London, 2005. For a description of the early moves around the reorganization of Romanian Securitate, which were considered by the authors of the Proclamation of Timisoara, see generally Kieran Williams \& Dennis Deletant: Security Intelligence Services in New Democracies. The Czech Republic, Slovakia and Romania, Palgrave MacMillan, 2001. It should be noted that Timisoara was the town where the Romanian anticommunist revolt started in 1989, and where the killing and repression were severe. As time went by and Iliescu and his organization, the National Salvation Front, were unable to produce the authors of the killing, but several known perpetuators appeared on his entourage, the people participating in the revolt grew more and more impatient. The series of manifestations and street protests, albeit organized by a minority of the population, continued in several Romanian towns almost incessantly, until after the Romanian first 'post-communist' elections of May 1990. Timisoara was at the time the second town in importance after the capital to organize such manifestations, but as a moral symbol was considered even more important than the capital, Bucharest, as its people were the first to revolt against Ceausescu. In June 90 Iliescu decided to call upon the miners from 'Valea Jiului', a central part of Romania, to put an abrupt end to such manifestations in Bucharest, the capital. The ensuing generalized civil conflict and the scenes of brutality which where broadcasted around the world made from Iliescu and his regime an instant international pariah and raised serious questions about the democratic commitments of Romania.

50 The whole text of Point 8 is as follows: "As a consequence of previous point, we propose that the electoral law shall prohibit for the first three consecutive legislatures the right to compete, on any political party's list, of any of the former communist activists or officers of Securitate. Their presence in the political life of the country is the main source of tensions and suspicions that churn the today's Romanian society. Until this situation is stabilized and the national reconciliation takes place, their absence from public life is an absolute necessity. We also ask for the introduction in the electoral law of a special paragraph which bans the former communist activists' candidatures for the office of the president of the country. The office of the President of Romania has to be one of our symbols of departure with communism. To be a member of the [communist] party is not a fault. We all know on what extent was conditioned the life of the individual under communism, from professional achievement to the receipt of a dwelling, by the red card, and what serious consequences could attach to its surrender. Activists, however, were those people who have abandoned the profession to serve the Communist Party and to enjoy special privileges offered by it. A man who made such a choice presents no warranties on the moral warranties of the kind which should be provided by a President. We also propose the reduction of the prerogatives of the Presidential office, after 
the model of many countries of the civilized world. Thus, for the office and dignity of President of Romania may apply personalities of cultural and scientific life, without a great political experience. In this context, we propose the first legislative term to be only two years, a time necessary for democratic institutions to be strengthened and for the many parties appeared [on political scene] to clarify their ideological position. For only then we could make a choice, with the books largely opened on our face." For the possible influence of the 'Timisoara' Declaration on other Central European States, see for example Csaba Varga: Transition to Rule of Law. On the Democratic Transformation in Hungary, Hungarian Academy of Sciences, Budapest 1995, at p.147 (stating that the first academic debate on dilemmas surrounding 'historical justice' in Hungary in January 1990 was attempt to formulate a response to preceding events in Timisoara and Bucharest).

51 See Vojtech Cepl, Ritual Sacrifices. Lustration in the CFSR, East European Constitutional Review, Vol. 1, No. 1, pp.25-26 (1993) for an earlier mention of lustration as a magic or ritualistic procedure. However, Cepl, as well as other authors, use idea of 'ritual cleansing', which they derived from a mistaken interpretation of the etymological origin of 'lustrace', more in an allegoric manner, to suggest the possible emptiness of a legal device inspired by a religious practice, and do not offer any arguments for the equivalence of lustration with a religious practice.

52 Besançon, Chapter 16. The Empire of the False, in Besançon, Les Origines, op. cit.

53 See Kieran Williams, in Williams, Fowler, Szczerbiak: Explaining Lustration in Central Europe: A post communist Politics approach, Democratization, Vol. 12, No. 1, (February 2005), pp.22-43.

54 Mircea Eliade: Le Sacre et le Profane, Gallimard, 1987.

55 As 'collective memory' plays an important role in such processes, we should note in passing the great interest toward collective memory in the recent historical scholarship and the consequent revival of cultural history. However because the field is still striving to obtain significant conceptual and methodological advances in the research of collective memory processes, there are not yet definitive findings which could add to our argument, and therefore an overview of the themes of the voluminous 'collective memory' is not necessary. (See Wulf Kansteiner: Finding Meaning In Memory: A Methodological Critique of Collective Memory Studies, History and Theory, Vol. 41, (May 2002) pp.179-197. Suffice it to indicate that in the elaboration of a new democratic identity 'collective memory' processes play a role.

56 The French Vichy syndrome might come immediately to the mind (See Henry Rousso: Le syndrome de Vichy, de 1944 a nos jours, 2eme Edition Revue et Mise a Jour, Editions du Seuil, 1990). For an explanation on how Vichy was made possible by the legal culture, and the many missteps of the French postwar legal system in dealing with the past see Vivian Grosswald Curran: Fear of Formalism: Indications from the Fascist Period in France and Germany of Judicial Methodology's Impact on Substantive Law, 35 Cornell Int'l L.J. 101 (2001) and Leila Sadat Wexler: The Interpretation of the Nuremberg Principles by the French Court of Cassation From Touvier to Barbie and back again, 32 Colum. J. Transnat'l L. 289 (1994).For the more general European politics of forgetting after the WWII, and the price to be paid in 1968 and more recently, in the last decade of the XX century when Nazi parties were reviewed in parts of Western Europe see generally Tony Judt, Postwar, Chapter I Retribution, in Tony Judt, Postwar, op, cit.

57 These words were used to describe the West German Republic politics in regard to the past and the long process of reckoning with the atrocities of the Nazis era.

58 For a general description of the multifaceted German process see Robert G. Moeller: Review: What Has 'Coming to Terms with the past' Meant in Post-World War II Germany? From History to Memory to the 'History of Memory', Central European History, Vol. 35, No. 2 (2002), pp.223-256. For developments after 1989, see Jeffrey K. Olick: What Does It Mean to Normalize the past? Official Memory in German Politics since 1989, Social Science History,22:4 (Special Issue: Memory and the Nation (Winter, 1998), pp.547-571. For the what the process meant for the legal system, see the seminal contribution of Ingo Muller: Hitler's Justice. The Courts of the Third Reich, I.B Tauris \& Co, Ltd Publisher., London, 1991. 
59 See Theodor W Adorno: What Does Coming to Terms with the Past Mean?, (Geoffrey Hartman translation of Adorno's: "Was bedeuted: Aufarbeitung der Vergangenheit" 1959, Surhkamp Verlag, Frankfurt am Main, 1963). It is interesting to note that Adorno seems to have a conception which meets along the way the Rawlsian ideas of distributive justice. We should also note that Adorno has in the above text two other observations which might seem appropriate, at least partially, to describe the ECE post-communist context: "[t]he impression is created that the guilt-which so many fend off, abreact, or deflect through the craziest rationalizations-is really no guilt at all, but exists only inside them in the psychological makeup. So a real and terrible past is rendered harmless by being transformed this way-into a merged figment of the imagination of those who are affected by it. Or is guilt itself perhaps only a complex?", and: "[t]he best to be said is that political democracy has been accepted in Germany as what Americans call a 'working proposition'-something functional that up till now has allowed and even promoted prosperity. But democracy has not domesticated itself to the point that people really experience it as their cause, and so consider themselves agents of the political process. It is felt to be one system among others, as if one could choose from a menu between communism, democracy, fascism, monarchy-meant not as something identical with people themselves, as the expression of their own maturity. Democracy is valued according to its success or failure, whereby special interests must also come into play, rather than as the union of the individual and the collective interest."

60 With several disclaimers, this assessment of the activity of former communist secret services in post-communism is generally shared by Kieran Williams and Dennis Deletant who focused on the post-communist secret services as democratic secret services (see Williams \& Deletant, Security Intelligence Services in New Democracies,op, cit).

61 Berendt, op. cit.

62 Senyi Andras Koro: Revival of the Past or New Beginning? The Nature of Post-Communist Politics". Political Quarterly, Vol. 62, No. 1, pp.52-74, (1991); Jadwiga Staniszki: Political capitalism in Poland, East European Politics and Societies, Vol. 5, pp.127-141 (1991). The literature exploring these themes is too voluminous, and to diverse in its themes to attempt here a systematization and to indicate even tentatively its authors. So we indicated Koro and Staniszk is just as examples, with the hope not to doing injustice to authors who deserve acknowledgement, such as Erzebet Szalai, Caroline Humphrey, Katherine Verdery or IvanSzelenyi.

63 See just with the title of example Katherine Verdery: What was socialism and what comes next, Princeton University Press. 1996; Joan Nelson, Charles Tilly and Lee Walker (Eds.): Transforming Post-Communist Political Economies/Task Force on Economies in Transition, Commission on Behavioral and Social Sciences and Education, National Research Council, National Academy Press, Washington DC, 1997; Gil Eyal, Iván Szélényi and Eleanor Townsley: Making Capitalism Without Capitalists. London, Verso, 1998; Maria Los and Andrzej Zybertowicz: Privatizing the Police State. The Case of Poland, MacMillan Press Ltd for the Great Britain edition, 2000. On transformations of state and power in post-communism see tentatively Arista Maria Cirtautas: The Post-Leninist State. A Conceptual and Empirical Examination, Communist and Post-communist Studies, Vol. 28, No. 4, (1995), pp.379-392; Valerie Bunce: Subversive Institutions: The Design and Destruction of Socialism and the State, Cambridge University Press, 1999; Venelin I. Ganev: Dysfunctional Sinews of Power. Problems of Bureaucracy-Building on the Postcommunist Balkans(paper presented at the conference on "Civil Society, Political Society and the State: A Fresh Look at the Problems of Governance in the Balkan Region," Split, Croatia, November 23-24, 2001), Venelin I. Ganev: The Dorian Gray effect: winners as state breakers in post communism, Communist and PostCommunist Studies, Vol. 34, (2001) pp.1-25; Venelin I. Ganev: The Separation of Party and State as a Logistical Problem: a Glance at the Causes of State Weakness in Post communism, East European Politics and Societies, Vol. 15, No. 2, (2001), pp.389-420 and Venelin I Ganev: Preying on the State. The Transformation of Bulgaria after 1989, Cornell University Press (2007). A review of several main themes of the social theory in post-communist studies is provided by William Outhwaite and Larry Ray. See William Outhwaite and Larry Ray: Social Theory and Post communism, Blackwell Publishing, 2005, at pp.7-12. 
64 Venelin I Ganev: Preying on the State. The Transformation of Bulgaria after 1989, Cornell University Press (2007), and Venelin Ganev, op, cit, at p.141.

65 Ellen Comisso: Legacies of the Past or New Institutions, Comparative Political Studies, Vol. 28, No. 2, (1995), p.235.

66 Katherine Verdery has these pertinent observations in respect to the survival and enhancement of the socialist enterprise role in post-communism: "These emerging patterns of encystment and transience were a logical outcome of certain features of work organization in socialist firms-which as Simon Clarke suggests, had a certain affinity with feudalism." The soviet enterprise is almost as different from the capitalist enterprise as was a feudal estate from a capitalist farm. Like the feudal estate, the socialist enterprise is not simply an economic institution but is the primary unit of soviet society, and the ultimate base of social and political power. This unit provided all manner of services and facilities for its labour force (housing, kindergartens, sporting and cultural facilities, clinics, pensions, etc). The collapse of the party state reinforced the tendencies of personalism and patronage inherent in such arrangements, making many people dependent on their locality, their workplace, or their boss for access to food, housing and loans. Belonging to a suzerainty, by having a regular job or enjoying some other tie to a powerful and successful patron, meant dependence, but as in feudal times it also meant at least minimal security." Verdery, op. cit. at p.200. For the characteristics and incentives to elites offered by the post-socialist state, see generally Venelin Ganev, op. cit.

67 A degree of collaboration with the secret communist police was mandatory for the top management of enterprises in the so called 'sensitive' branches of national economy, considered of high importance by the communist party, or in the case of the enterprises organized by the security services themselves with the approval of the top echelons of communist parties. There were many such enterprises in all the communist ECE countries, and a detailed legal-economic analysis of their mode of functioning will not add much to the argument. Suffice it to indicate that Maria Los, supra, gives a description of the ways in which such enterprises were organized in Poland towards the end of the communist regime, description which in our view generally fits the ways in which such enterprises were transformed in post-communist ECE.

68 In fact, the selection started much earlier, during the primary and high school when the student enrolled in the communist youth, usually a precondition to become a member of the communist party, and also in the university, where the political activity of the student was taken in consideration for higher grades. Between two students of equal capacity and preparation, the final differentiation in grades was given by the political activity. If one had activity in communist youth during the university and the other has no activity, the activist received the highest grades, which place him better for occupying the best positions at the end of study, as the system of distribution of graduates was highly centralized. Of course, such obscure 'selection' effectuated on the basis of operational codes and not on enacted laws operated during the whole professional life. For a brief description of such operational codes and their effects in post-communism, in a paradigmatic case of Czechoslovak law schools, see Aviezer Tucker: Paranoids May Be Persecuted, in Jon Elster (Ed.): Retribution and Reparation in the Transition to Democracy, Cambridge University Press (2006), at pp.183-185.

69 The communist directors of enterprise would thus cover all the psychological types of wrongdoers described by Jon Elster (see Elster, supra, EN.70, Chapter 5 Wrongdoers, in Elster, Closing the books, at p.137 and subseq.), with probably a dominance of opportunists and conformists, the "parasites on the wrongdoing regime, rather than its driving and sustaining force", as argued by Elster.

70 In literature are mentioned also other reasons for the post-communist absence of such exclusionary inclusion, as for example the negotiated character of the anticommunist political 'revolutions' of 1989, the absence of a wide poll of untainted qualified candidates for the positions occupied by the communist technocrats.

71 Jon Elster, 'Closing the books'... op. cit. Elster posits that the emotions, which constitute the basis for administrative justice demand, do not decay with the passing of time if communication among the victims, visible physical reminders of the wrongdoing, and 
perpetuation of the state of affairs caused by wrongdoing is taking place in transitions to a democratic regime. Arguably all these conditions were met at least in the first decade of post-communist transition in the ECE.

72 See Jacques Rupnik: From Democracy Fatigue to Populist Backlash, op.cit, and Ivan Krastev: Is East Central Europe Backsliding? The Strange Death of the Liberal Consensus, Journal of Democracy, Vol. 18, No. 4, (October 2007), pp.56-63. Krastev speaks in these terms about the legacy of the first years of POST-communist transformations: "The populists' obsession with corruption is the most powerful expression of this new understanding of the meaning of politics. The new populist majorities perceive elections not as an opportunity to choose between policy options but as a revolt against privileged minorities - in the case of Central Europe, corrupted elites and morally corrupting 'others' such as ethnic or sexual minorities."

73 Romania, Bulgaria, Czechoslovakia, Poland, and Germany, for example, instituted during the earlier stages of the transition, or had considered the initialization of criminal prosecutions against communist agents for violent crimes or serious human rights abuses committed during the communist regimes. On this account see for example Upheaval in the East: Army Executes Ceausescu and Wife for 'Genocide' Role, Bucharest Says, N.Y. Times, Dec. 26, 1989, at Al, col. 6; Evolution in Europe: Ceausescu's Fallen Heir Faces Court, N.Y. Times, May 27, 1990, at 14, col. 4; Inquiry on Deaths Going Nowhere in Romania, N.Y. Times, Feb. 14, 1991, at A10, col. 1; Czechoslovakia Detains Ex-Communist Party Leader and 4 Others, N.Y. Times, June 7, 1990, at A10, col. 1; Bulgaria Presses Inquiries into the Communist Past, N.Y. Times, June 6, 1991, at A15, col. 1; Bulgaria's Ousted Dictator Agrees To Face His Accusers, N.Y. Times, July 19, 1990, at A6, col. 5; Poland Arrests 2 Police Generals in '84 Killing of Reformist Priest, N.Y. Times, Oct. 9, 1990, at A8, col. 3; Prosecutors for Unified Germany Seize Former Communist Officials, N.Y. Times, Oct. 7, 1990, at 14, col. 1; Honecker's Arrest Sought in Berlin Wall Shootings, N.Y. Times, Dec. 2, 1990, at 23, col. 1; Honecker Taken to Soviet Union; Germany Demanding His Return, N.Y. Times, Mar. 15, 1991, at Al, col. 1; 4 Ex-Officials of East Germany Arrested, N.Y. Times, May 22, 1991, at A3, col. 4; Berlin Wall Guards Accused of Shooting Escapees, N.Y. Times, June 16, 1991, at 6, col. 1; End of the Line: Leaders at Communism's Finish, N.Y. Times, Nov. 16, 1990, at A16, col. 1. Less than a decade and a half after these announcements, one of the commentators of transitional justice could write "In Eastern Europe there have been relatively few prosecution for wrongdoings committed under communism". So to some extent a veil has been thrown over the past, after the first years of transition and the change in the mood is well reflected by the press. (Jon Elster: Closing the Books: Transitional Justice in Historical Perspective, Cambridge University Press, 2004, at p.117): A brief search with key words such "prosecution of ex/former communist leaders in Europe" in leading newspapers, as the New York Times, Washington Post, The Times, or Guardian, for the period between 2005 and 2008 returned a scarcity of results.

74 Roman David \& Susanne Choi Yuk-Ping: Victims on Transitional Justice: Lessons from the Reparation of Human Rights Abuses in the Czech Republic, Human Rights Quarterly, Vol. 27, (2005), pp.392-435. David and Choi have this pertinent remark in regards to the scarcity of studies dedicated to the study of communist victims in the post-communist settings: "Despite victims being the direct beneficiaries of reparation programs, and despite the fact that macro political decisions of how to deal with the past are often justified by their desires, there are few studies of the victims. In part, this reflects the lack of empirical research in the field of transitional justice.

75 With regards to such perils see generally Inga Markovits, Selective Memory: How the Law Affects What We Remember and Forget about the Past: The Case of East Germany, Law \& Society Review, Vol. 35, No. 3, (2001), pp.513-563.

76 See Claus Offe and Ulrike Poppe: Transitional Justice in the German Democratic Republic and in Unified Germany, in Elster, Closing the books, supra, EN 70, at p 239. As used here, the term political regime encompasses not only the mechanisms of government and the institutions of the state, but also the structures and processes through which these interact with the larger society. Although the communist takeover in Central East Europe after the WWII is a transition, as is the fascist take over in most of the Europe before and during the WWII, were studied as transition by scholars, and therefore the relationship enounced here apply to those 
transitions as well, when we speak about "the studies on the political transitions" we have in mind the modern scholarship on the transitions to democracy. For a review of such studies on the transition to democracy and the theoretical problems raised by them see generally Gerardo L Munck: The regime question. Theory building in Democracy Studies, World Politics, Vol. 54, No. 1, (October 2001), pp.119-144.

77 For the relationship of the individual to the political collective and its restructuring in time of radical political transformations, see Rudi Teitel, Transitional Justice, supra, at p.151.

78 The potential radicalism of such relationships establishment in case of rupture in regime become evident if one thinks at what happens in social phenomena called revolutions. See for example the late Marin Malia: History Locomotives. Revolutions and the Making of the Modern World (Edited and with a foreword by Terrence Edmons), Yale University Press, New Haven \& London, 2006.

79 For the oldest documented European cases of democratic transition, that of Athens in 411 and 403 BC, see Jon Elster : Closing the Books, supra, EN 70 at p.3 and subseq. For the earlier example of the role of collective sanctions in political transitions see Rudi Teitel reference to the biblical story of Sodom and Gomorrah, in Teitel, supra, at pp.151-152.

80 As for example those characterizing the terror period of the French revolution or the first years of the Bolshevik revolution.

81 As those after 1989 in the former communist Central Eastern Europe.

82 In reality even for the arbitrary regimes functions the rule of giving at least some sort of reasons for their dealings with the former regimes actors and subjects.

83 On the relationship between reason, justification and authority in democratic polities see generally J. Raz (Eds.): Readings in Social and Political Theory. Authority and Justification, New York University Press, 1990, and in particular J. Raz: Authority and Justification, at p.115 and G.E.M Ascombe: On the sources of the Authority of the State, at p.145.

84 See for example Claus Offe and Ulrike Poppe: Transitional Justice in the German Democratic Republic and in Unified Germany, at p.239.

85 For a comprehensive constellation of the cases of that period see generally Istvan Deak, Jan T Gross and Tony Judt (Eds.): The Politics of Retribution in Europe. World War II and Its Aftermath, Princeton University Press, 2000; Tony Judt: Postwar. A History of Europe since 1945, Pimlico, 2007, pp.41-62; and John Elster (Ed.): Retribution and Reparation in the Transition to Democracy, Cambridge University Press, 2006, chapters 4-8. While for the communist regimes the two simultaneous requirements enunciated above were mere 'bourgeois niceties' of no use for their 'popular tribunals' which had to deal speedily and forcibly with the fascists 'enemies of the people', it is at least debatable if the two simultaneous requirements were strictly and always observed by the restored democratic regimes in their cases of criminal punishment of former fascists or collaboration with the Nazis.

86 See Rudi Teitel, supra, at p.167: "Modern liberal democracies are generally constrained from decision making in the public domain on purely political grounds."

87 See for example Scott Veitch, Emilios Christodoulidis and Lindsay Farmer: Jurisprudence, Themes and Concepts, Routledge-Cavendish, 2007, at p.62 and subseq. Accordingly to a widely shared although circumscribed definition the term 'Transitional justice' characterizes the choices made and quality of justice rendered when new leaders replace authoritarian predecessors presumed responsible for criminal acts in the wake of what Samuel Huttington called the "third wave of democratization."

88 Given the general propensity of authoritarian regimes to conceal and destroy the incriminatory proofs, the tensions between the criminal punishment for political past actions and the law's general principle non-retroactivity, and in general, the contradictory and theoretically underdeveloped nature of crimes.

89 The potential reach of political and administrative sanctions has therefore a sphere a lot more extensive than the criminal punishment. 
90 In addition to the criminal law codifications in each country, there is also a more or less stable body of international law which could assist the internal criminal law substantial law issues With the title of example, see generally Diane F. Orentlicher: Settling Accounts: The Duty to Prosecute Human Rights Violations of a Prior Regime, ${ }^{100}$ YLJ 2537 (June, 1991); Naomi Roht-Arriaza, Sources in International Treaties of an Obligation to Investigate, Prosecute, and Provide Redress, in Impunity and Human Rights in International Law and Practice, Vol. 24, No. 24, (1995); Steven S. Ratner and Jason S. Abrams: Accountability for Human Rights Atrocities in International Law. Beyond the Nurnberg Legacy, Second Edition, Oxford University Press, 2001; Louis B. Sohn: The New International Law. Protection of the Rights of Individuals Rather than States, 32 Am. U. L. Rev. 1 (1982).

91 In reality, the spirit of the regime to which the reversion occurred was not exactly the Enlightenment one, but more a sort of refined version of it, which filtered two centuries of ideological ups and downs in capitalist societies. So Eric Hobsbawm insights in respect to the fatigue of last years of the twenty century "In short, the (XX-o.n) century ended in a global disorder whose nature was unclear, and without an obvious mechanism for either ending it or keeping it under control. The reason for this impotence lay not only in the genuine profundity and complexity of the world crisis, but also in the apparent failure of all programmes, old and new, for managing or improving the affairs of the human race" (Hobsbawm. Age of extremes, Short Twentieth Century, pp.563-664) are probably the best to describe the immediate ordering possibilities of this refined version of Enlightenment when colluding with the reversal of an ideological age political system.

92 In other words, the old question raised by Camus after the liberation of not 'if', but 'who and how'. See Tony Judt: The Past is Another Country, in Deak, Gross and Judt, op. cit. at p.295.

93 There is a convincing body of research which points towards the differences in treatment between the former regimes actors submitted to vetting procedures immediately after regime changes in comparison to those submitted to vetting procedure after the elapse of a period from the change. As the time goes by, there is more opportunity to evaluate the adaptation of the former regime agent to the new environment. See for the example of the former GDR John Borneman, Settling Accounts. Violence, Justice, and Accountability in Postsocialist Europe, Princeton University Press, 1997.

94 Similarly to other fluid and elastic post-communist concepts, as that of the 'land' for example. See Katherine Verdery: What was Socialism and what comes next, Princeton University Press, 1996, at p.134. I am indebted to Katherine Verdery for the idea of fluid and elastic boundaries in the post-communist concepts. For discourses related to truth in the context of lustration debates see also Maria Los: Lustration and Truth Claims: Unfinished Revolutions in Central Europe, Law \& Social Inquiry, Vol. 20, No. 1, (Winter, 1995), pp.117-161.

95 There are too many such scandals to attempt to indicate them even tentatively. With the title of example, see for the Hungarian case, János M. Rainer, 1956 Institute for the History of Hungarian Revolution, Budapest, Hungary: Opening the Archives of the Communist Secret Police - the Experience in Hungary, on line at:

http://www.rev.hu/portal/page/portal/rev/tanulmanyok/rendszervaltas/rmj_oslo_00_eng_long, for the Czech, Slovak and Romanian cases see generally Kieran Williams \& Dennis Deletant: Security Intelligence Services in New Democracies. The Czech Republic, Slovakia and Romania, Palgrave MacMillan, 2001, and for the Polish case see generally Maria Los and Andrzej Zybertowicz: Privatizing the Police State. The Case of Poland, MacMillan Press Ltd for the Great Britain edition, 2000.

96 The country most 'aggressive' was the Czech Republic, which enacted in 1996 the Act 140/1996 on Access to secret Files. Although the 1991 Screening Law was based on the Communist regime secret service archives, we do not equal the governmental bodies' access to these archives with a comprehensive public access to these archives. For a comprehensive ECE wide comparison of various laws for public access see Table 2: Access to CommunistEra Secret Archives in Lavinia Stan: The Politics of Memory in Post-Communist Europe. A Comparative Analysis, Paper presented to the Colloque « Expériences et mémoire: partager en français la diversité du monde »Bucarest, Septembre 2006, on file with the author, at p.7. We should note the notable exception to this general trend of the former GDR. 
97 Maria Los and Andrzej Zybertowicz: Privatizing the Police State. The Case of Poland, MacMillan Press Ltd for the Great Britain edition, 2000.

98 For such an argument in the context of Czechoslovak lustration law see Jirina Siklova: Lustration or the Czech Way of Screening, 5.E. Eur.Const. Rev. 57 (1996).

99 If the communist secret services were destroyed or tainted, all the information found there should be discarded is a strong version of this argument.

100 Andrew Heywood: Politics, Palgrave, 2002, at p.26.

101 The late Corneliu Coposu, a Christian Democratic politician leader of the Romanian National Peasant Party and an important political figure of the first decade of the Romanian transition after a remarkable transformation from public enemy of the 'new regime' to the national most important moral figure, was a survivor of more than twenty years of harsh communist extermination camp and a former political hope of the interwar prominent Romanian Peasant Party.

102 A nomenklaturist and a great political hope of the Romanian communist party, before and after his golden exile as a second rank nomeklatura member order by Ceausescu himself as a result of Iliescu's more reformed vision of the communism.

103 With the exception of some dedication and commitment to economic reform and democratic change, whatever this reform or change meant. It is ironic how the subject of economy, painfully avoided by the dissidents before the communism fall because of the taboo imposed by the communist regime, became under the constraints of the transformation the first and foremost one to be tackled. On the avoidance before the fall of communism of the subject, and its causes, see Tony Judt: The Dilemmas of Dissidence. The Politics of Opposition in East-Central Europe, East European Politics and Societies, 1988: Vol. 2, pp.185-240. On why the changes priorities in dealing with communism were probably correct, see generally the explanation of core problem of socialism in Katherine Verdery: What was Socialism and Why did it fall? in What was socialism, op.cit, at p.19, or in her more earlier and extended commentary: Katherine Verdery, Theorizing Socialism: A prologue to the 'Transition', American Ethnologist, Vol. 18, No. 3 (representations of Europe: transforming state, society, and identity) (August 1991), pp.419-439. For the idea that there was no clearly dominant plan or project of post-communist transformation because there was no victorious counter-elite (as in revolutions in the proper sense) to prevail over the old regime and consequently derive unequivocal legitimacy and a mandate for action see Jon Elster, Claus Offe, and Ulrich K. Preuss (with Frank Boenker, Ulrike Goetting, and Friedbert W. Rueb): Institutional Design in Post-communist Societies. Rebuilding the Ship at Sea, Cambridge University Press, 1998, at p.15.

104 The only major rule which was firmly established in the CCE region was that the government should come and go based on the will expressed by the majority in free elections. This is the first and major rule of a democracy, and it was firmly established, from the beginning in the new democracies of the region.

105 See Williams Intelligence services in new democracies, op.cit (Williams \& Deletant). corroborated with the personal accounts of prominent officials during the transformation: Jan Frolík, Transformation of the Interior Ministry and Security Forces, p.103; Jan Ruml, My Time at the Interior Ministry, at p.111, Jan Eichler, Army Transformation, at p.99 and Petr Zeman, The Transformation of the Intelligence Services at p.115 (Experiences of Czech transitions, published on line by People in Need foundation at http://clovekvtisni.cz/dowload/pdf/65.pdf).

106 Mark Gibney: Decommunization: Human Rights Lessons from the Past and Present, and Prospects for the Future. Denver Journal of International Law and Policy, Vol. 23, No. 1, pp.87-133.

107 For the perception of the Czech Republic as a corrupt democracy despite its efforts with the lustration and purges, see for example Jeffrey M Jordan: Patronage and Corruption in the Czech Republic SAIS Review, Vol. 12, No. 2, (Summer-Fall 2002), pp.19-50. The literature on 'corruption' facilitated by transition from authoritarian regimes had became already too wide to even entertain the indication of a selective bibliography despite the fact that 
'corruption', as a concept for the analysis of democratic transitions, became fashionable almost a decade after the 1989 revolutions, and for the analysis of the industrialized west democratic polities even later. Nevertheless, in early 90's Italy entered in the 'Many Pulite' era, and for the students of the study post-war Europe developments, it was somehow clear that politics of stabilization could lead to great corruption and patronage, and to systems which only formally mimic those most democratic of the industrialized west. For later scholarship on the politics of stability which led to corruption and patronage in capitalist post-war Europe, see for example Tony Judt's description of the case of Italy, in Tony Judt, Postwar, op. cit.(Chapter The Politics of Stability), at p.258 and subseq, or Judt's the description of the Austrian 'proportz'. For later scholarship on Italy, see for example Miriam A. Golden: Electoral Connections: The Effects of the Personal Vote on Political Patronage, Bureaucracy and Legislation in Postwar Italy, 33 B.J. Pol. S. (2003) pp.189-21; and especially the systematic study of Donatella Della Porta, Alberto Vannucci: Corrupt exchanges: actors, resources, and mechanisms of political corruption, Aldine Transaction, 1999. For a more extensive constellation of cases, including Northern and Southern Europe or Asia, see Martin J. Bull, James Newell: Corruption in contemporary politics, Palgrave Macmillan, 2003. For Latin America see for example: Charles H. Blake, Stephen D. Morris (Eds.): Corruption and Democracy in Latin America, University of Pittsburgh Press, (May 28, 2009).

108 In general we should observe that the measurement of influence of lustration on the popular trust in the democratic institutions, respectively on the legitimacy of such institutions in postcommunist transitions, is a difficult enterprise. The surveys of the period generally measured the general level of population's "the trust in various democratic institutions, and no surveys containing trust and legitimacy as variables of lustration were conducted. In the absence of such surveys a general approximation of the interplay between lustration and trust and legitimacy could was usually done by using proxies. Such proxies are for example the popular vote for ex communist parties which opposed explicitly in their political platforms to lustration measures, or the comparisons of level of trust in democratic institutions between ECE countries applying different lustration measures. Such proxies are problematic, and could be used at best only for an indirect argument. In the case of the vote for ex communist parties, for example, lustration was at best a marginal topic in such parties' political platforms or elections debates, and it could not be easily isolated among the other issues of the period. Moreover, its importance in the vote for ex communist parties could not be easily ranked, and is difficult to discern among the ex communist parties voters for whom determinant for the vote was the position adopted by these parties towards lustration. If we see the vote for ex communists in Hungary and Poland in 1994 as a negative response to the economic decline provoked by the economic measures adopted by the first post-communist governments, as it is seen sometimes in the literature, we could further doubt that the ex communist parties opposition towards lustration measures was so important in attracting votes towards these parties. Finally, the comparative assessment of the level of trust in democratic institutions among the ECE countries applying different lustration measures is also problematic, as the trust is not perhaps more influenced by the efficacy or perceived fairness of such institution than by lustration. However, on the basis of such comparisons it could be rejected at best the argument that lustration and purges lowered the level of trust in democratic institutions. For a general evaluation of the higher trust in rapport with the pessimistic predictions of the former GDR population public trust in the institutions imposed by Western Germans, see John Borneman, Settling Accounts. Violence, Justice and Accountability in Postsocialist Europe, Princeton University Press, 1997. For an evaluation and general assessment of trust in democratic institutions in the ECE post-communist first decade, see generally William Mishler and Richard Rose: Trust, Distrust and Skepticism: Popular Evaluations of Civil and Political Institutions in Post-Communist Societies, The Journal of Politics, Vol. 59, No. 2, (May, 1997), pp.418-451. The general evaluation of the first major study public study published in 1998, was that post-communist societies in East Central Europe (ECE) "was characterized by low levels of trust in the new political institutions of democracy".W.L. Miller, S. White, P. Heywood: Values and Political Change in Postcommunist Europe, Macmillan, Basingstoke (1998), at p.100. While in the absence of direct measurements of the influence of lustration on trust it is impossible to theorize on lustration impact alone in the enhancement of level of trust in democratic institutions of the region, the last study at least support the refutation of anti 
lustration proponents argument, that lustration destabilizes the trust. As arguably during that time, with the exception of the former Czechoslovakia and GDR no ECE country implemented comprehensive lustration, the argument that lustration destabilize the level of trust is not supported.

109 For the low levels of trust, see William Mishler and Richard Rose: Trust, Distrust and Skepticism: Popular Evaluations of Civil and Political Institutions in Post-Communist Societies, The Journal of Politics, Vol. 59, No. 2, (May, 1997), pp.418-451. The general evaluation of the first major study public study published in 1998, was that post-communist societies in East Central Europe (ECE) "was characterized by low levels of trust in the new political institutions of democracy" .W.L. Miller, S. White, P. Heywood: Values and Political Change in Postcommunist Europe, Macmillan, Basingstoke (1998), at p.100. For corruption, see for example Maria Los: Crime in transition: The post-communist state, markets and crime, Crime, Law \& Social Change, Vol. 40, pp.145-169, (2003); András Sajó:From corruption to extortion: Conceptualization of post-communist corruption, Crime, Law \& Social Change, Vol. 40, pp.171-194, (2003); Maria Los:Post-communist fear of crime and the commercialization of security, Theoretical Criminology, Vol. 6, No. 2, (2002), pp.165-188; András Sajó: Corruption, Clientelism, and the Future of the Constitutional State in Eastern Europe, East European Constitutional Review, Vol. 7, No. 2 (Spring,1998), p.39.

110 It is interesting to observe than one of the objection related to the enactment of lustration laws was the contention that lustration, as well as prosecution, or other punitive measures fail to achieve extensive moral, legal and political ends sought in by the successor polity, such as the advancement of respect for the rule of law or tolerance of peaceful political dissent. However, as the former GDR statistical polls suggest, comprehensive lustrations and purges imposed even from outside did not necessary lower the level of trust and legitimacy of the democratic institutions or the rule of law, in comparison with countries which did not traversed such purges. Moreover, when combined with the establishment of new and efficient law enforcement agencies, capable to enforce the law impartially and to curb the economic criminality made possible by the large transformations of economy, the trust in democratic institutions or the rule of law was even greater in the former GDR than in the countries which did not implement lustration or purges. Evidently that the enactment or implementation of lustration and purges alone were not sufficient to enhance the legitimacy and public trust in democratic institutions to the level reached in the countries which combined lustration with other comprehensive reform of post-communist bureaucracies, as a comparison between Czechoslovakia and the former GDR, the two ECE countries that enacted lustration measures early and applied the thoroughly suggests. If, as in the case of Czechoslovakia, the reform is piecemeal, proceeds hesitantly, and combines with other defects of democratic institutions and transformations, with or without lustration the new bureaucracies are not perceived by the public as well as the post-communist bureaucracies are perceived in the countries which combined lustration with other comprehensive reforms of bureaucracies (GDR). Therefore, what seems to count most in rapport to public perception is how the bureaucracies are reformed and able to perform effectively. Nevertheless, the indications that lustration and purges alone did not lead to levels of public trust and enhancement of the legitimacy of post communist democracy comparable to countries which accompanied such measures with comprehensive other reforms are not proofs that lustration and purges failed to achieve the desired goals. Moreover, the alternative, with no lustration, vetting or reform as applied in most of the former USSR space provide ample evidence of post-communist evolutions in polities which barely have any resemblance with democracies. So it could be said that the post communist experience with lustration in the ECE and former USSR space, rather than providing a clear case against lustration, it provides more a case for the negative implications of amnesia and amnesties in respect to democratic consolidation.

111 Luc Huyse: Justice after transition. On the Choice Successor Elites Make in Dealing with the Past, op.cit at p.51.

112 See Monica Nalepa: To Punish the Guilty and Protect the Innocent. Comparing Truth Revelation Procedures, Journal of Theoretical Politics, Vol. 20, No. 2, (2008), at pp.221-245, called the second generation of lustration laws, the laws which include "the kind of institutional mechanism" which introduces introducing incentives in transitional justice 
designs of lustration laws for the avoidance of the errors of false acquittal and false conviction. A variant of such mechanism is contained in the Romanian Law on Desconspiration of Securitate, described by Lavinia Stan, supra, EN 97, and by the electoral and other legal norms requiring the holders of public offices to disclose their collaboration with the communist secret police. In Cath Collins's taxonomy, this would be "post transitional justice" See supra, EN 11.

113 Marek Safjan: The vanishing truth? Politics and memory in post-communist Europe, East European Quarterly, on line at: http://www.ejls.eu/2/29UK.pdf (last visited October 2011). 